Policy Research Working Paper 2716

Does Foreign Bank Penetration Reduce Access to Credit in Developing Countries?

Evidence from Asking Borrowers

George R. G. Clarke

Robert Cull

Maria Soledad Martinez Peria
How does entry by foreign

banks affect lending to small and medium-size enterprises in developing countries? Analysis of data from a large cross-country survey of enterprises finds that foreign bank entry benefits firms of all sizes, although it seems to benefit larger firms more.

The World Bank

Development Research Group

Finance

November 2001

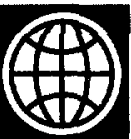


Policy Research Working Paper 2716

\section{Summary findings}

Existing evidence on the effect of foreign bank penetration on lending to small and medium-size enterprises is ambiguous. Case studies of developing countries show that foreign banks lend less to such firms than domestic banks do. But cross-country studies find that foreign bank entry fosters competition and reduces interest rates, benefits that should extend to all firms.
Clarke, Cull, and Martinez Peria use data $f^{\circ}$ om a large cross-country survey of enterprises to investigate this issue. Their results suggest that foreign bank penetration improves financing conditions (both the quantities of financing and the terms) for enterprises of all sizes, although it seems to benefit larger firms more.

This paper-a product of Finance, Development Research Group-is part of a larger effort in the group to uniterstand the impact of entry by foreign banks on domestic banking systems in developing countries. Copies of the paper are available free from the World Bank, $1818 \mathrm{H}$ Street NW, Washington, DC 20433. Please contact Paulina Sintim-Aboagye, room MC3422, telephone 202-473-7644, fax 202-522-1155, email address psintimaboagye@ $a$ worldbank.org. Policy Research Working Papers are also posted on the Web at http://econ.worldbank.org. The authors may be contacted at gclarke@worldbank.org, rcull@worldbank.org, or mmartinezperia@worldbank.org. November 2001. (37 palges)

The Policy Research Working Paper Series disse inates the find ngs of work in progress to encourage the exchange of idias about development issues. An objective of the series is to get the, indings out quickly, even if the presentations are less than fully polished. The papers carry the names of the authors and should be cited accordingly. The findings, interpretations, and conclusions expressed in this paper are entirely those of the authors. They do not necessarily represent the vietw of the World Bunk, its Executive Directors, in the countries they represent. 


\title{
DOES FOREIGN BANK PENETRATION REDUCE ACCESS TO CREDIT IN DEVELOPING COUNTRIES? EVIDENCE FROM ASKING BORROWERS *
}

\author{
George R. G. Clarke, Robert Cull, and Maria Soledad Martinez Peria \\ Development Research Group \\ The World Bank
}

Keywords: foreign bank penetration, small business lending JEL: G21,G32

\footnotetext{
* Some of the data used in this paper are from the World Business Environment Survey (WBES) C2000 The World Bank Group. We would like to thank Gerard Caprio and Asli Demirgüç-Kunt for helpful comments and advice. We are also grateful to Luke Haggarty and Andrew Stone for their help with the WBES data. Contact information: Robert Cull, World Bank, 1818 H Street NW MC3-300, Washington, DC 20433. Phone: (202)473-6365. Fax: (202)522-1155. E-mail:rcull@worldbank.org.
} 



\section{INTRODUCTION}

In recent years, foreign banks have achieved an increasingly important role in many developing countries. In Argentina, Chile, the Czech Republic, Hungary, and Poland, foreigncontrolled banks hold over fifty percent of total banking sector assets. Although foreign bank penetration is more modest in other developing countries, including many in Asia, Africa, the Middle East, and the Former Soviet Union, it has increased in most countries over the past decade. While foreign bank entry might improve financial intermediation by increasing competition, improving stability, and enhancing sector efficiency, some observers have suggested that it might also have some adverse effects. Among other things, opponents argue that increased foreign bank penetration in developing countries might reduce access to credit, particularly for small and medium-sized enterprises (SMEs). So far, however, the empirical evidence on this issue has been ambiguous.

Recent cross-country studies find that entry by foreign banks increases both competition and banking sector stability, factors that should benefit all borrowers. Using an 80-country sample of developed and developing countries between 1988 and 1995, Claessens et al. (2000) find that entry by foreign banks reduced both the profitability and expenses of domestic banks. In line with these results, Barth et al. (2001c) find that net interest margins and overhead costs were lower in countries with fewer restrictions on entry into banking, whether for foreign or domestic banks. In addition, they also show that major banking crises were less frequent in countries with fewer limitations on foreign bank entry and ownership. ${ }^{1}$ Dages et al. (2000) argue that foreign bank penetration does not necessarily threaten financial sector stability by showing that foreign banks in Argentina and Mexico exhibited stronger and less volatile loan growth than 
domestic banks between 1994 and 1999. Finally, examining the behavior of U.S. bank claims on a broad set of countries since the mid-1980s, Goldberg (2001) finds that U.S. banks did not retrench their lending significantly following period of crises.

Aside from increasing competition and improving stability, there is evidence that foreign bank entry might also benefit borrowers in developing countries by improving banking sector efficiency. In contrast to studies of foreign bank entry in the United States, several papers on developing countries have found that foreign banks, which are often from developed countries, are more efficient than their domestic competitors. ${ }^{2}$ Furthermore, studies have found that foreign banks tend to expand into areas where local profit opportunities are greatest, consistent with the hypothesis that foreign investors utilize their know-how and human resources to restructure inefficient banks. ${ }^{3}$

Despite the benefits associated with greater competition, stability, and efficiency, opponents of foreign bank entry argue that this process might still harm small and medium-sized enterprises. One reason for this is that foreign entrants tend to be large (Focarelli and Pozzolo, 2000). Evidence from the United States indicates that large and organizationally complex institutions find it difficult to lend to informationally opaque small and medium-sized enterprises. ${ }^{4}$ These organizational diseconomies might explain why a number of studies have found that foreign banks appear to allocate greater shares of their lending portfolios to commercial and industrial loans, providing indirect evidence that foreign banks might be more important in the market for loans to large companies. Goldberg (1992) notes that foreign banks operating in the U.S. held $28.5 \%$ of all commercial and industrial loans, but only $22.6 \%$ of all banking assets. ${ }^{5}$ In addition, in a survey of 271 foreign banks operating in the U.S., Cho et al. (1987) find that $56 \%$ pointed to trade finance as a major area of specialization; $44 \%$ listed corporate banking; and $31 \%$ mentioned foreign exchange 
trading, all services that are likely to benefit large businesses disproportionately. Similarly, for Argentina in the late $1990 \mathrm{~s}$, Clarke et al. (2000) find that foreign banks devoted about $35 \%$ of their loan portfolios to manufacturing, while private domestic banks devoted less than $20 \%$ to that sector.

Direct evidence on small business lending in Latin America is largely consistent with the assertion that foreign banks lend less to small and medium-sized enterprises than to large firms. Berger et al. (2000) find that small businesses in Argentina were less likely than larger ones to receive any credit from large banks or from foreign banks. ${ }^{6}$ Also analyzing the case of Argentina, Escudé et al. (2001) find that while foreign banks allocated a smaller share of their lending portfolio to SMEs, they granted almost half of the total credit to this sector in the year 2000 . Looking at a larger set of countries, Clarke et al. (2001) find that foreign banks in Argentina, Chile, Colombia, and Peru generally lent a smaller fraction of their funds to SMEs than similar domestic banks in the late 1990s. However, they find that other factors might have mitigated this. First, they find that differences between foreign and domestic banks were far less pronounced for large banks than they were for small banks in all four countries. In fact, in two of the four countries, Chile and Colombia, their econometric analysis suggests that large foreign banks might actually have lent relatively more to SMEs than large domestic banks after controlling for other factors that affect lending to these businesses. Further, they find that the growth rate of real lending to SMEs was higher for foreign banks than for domestic banks in Peru, and was also higher for large foreign banks than large domestic banks in Argentina and Chile.

The evidence regarding increased lending to SMEs by large foreign banks found in Clarke et al. (2001) might be explained by recent changes in technology. Mester (1997) argues that advances in credit scoring methodologies coupled with enhanced computer power and increased data availability might change the nature of small business lending. These factors could make it less 
necessary for a bank to have a physical presence in all geographic areas in which it lends (Petersen and Rajan, 2000) and could help large foreign banks to overcome some of the diseconomies and difficulties in lending to small borrowers.

However, even if foreign banks continue to primarily focus on serving large customers, foreign entry might still benefit small borrowers. Competition for large customers could displace some domestic banks, forcing them to seek new market niches such as providing credit to SMEs. Consistent with this, Bonin and Abel (2000) find that as foreign bank penetration increased in Hungary some smaller domestic banks sought new market areas. Similarly, in a survey of banks from 78 countries, Jenkins (2000) finds that, 44 percent of those banks that lent to small and micro enterprises indicated that changed market conditions and increased competition in lending to large and medium-sized enterprises were the two most important reasons for doing so. ${ }^{7}$

As illustrated in the discussion above, studies that have focused on foreign versus domestic bank behavior (using individual bank balance sheet data) have not provided a definitive answer on the net effect of foreign bank entry on access to credit for small and medium-sized enterprises. Isolating the effect of foreign bank entry on domestic banks' lending from macroeconomic changes can be difficult in country case studies, especially since relatively few commercial banks operate in many developing countries. ${ }^{8}$ Furthermore, comparable crosscountry data on lending to SMEs is not easily available, especially since small local banks tend to be important in this area of lending. ${ }^{9}$

Rather than relying upon information from bank balance sheets, this paper uses responses from a survey of over 4,000 enterprises in 38 developing and transition economies, to study whether borrowers' perceptions regarding interest rates and access to long-term credit are 
positively associated with the presence of foreign banks. If the potential advantages of foreign bank entry - improved sector efficiency, a subset of domestic banks forced by competitive pressures into new market niches, and new credit scoring technologies - outweigh the general tendency of large foreign banks to eschew SME lending, borrowers should rate access to credit (both quantities and terms) as easier in countries with relatively high levels of foreign bank penetration. Thus, our analysis should help to sort out whether the benefits of foreign bank entry found in other cross-country studies accrue to all borrowers or only to a lucky subset.

The remainder of the paper is organized as follows. Section II describes the data used in this study. Section III discusses the estimation method. The empirical results are presented in section IV. Section V concludes.

\section{DATA}

The data used in this paper come from two main sources: the World Business Environment Survey (WBES) and a database on bank regulation and supervision compiled by Barth et al. (2001b). These data are supplemented with macroeconomic data from the World Bank's World Development Indicators. Table I provides a list of the 38 countries included in the sample, which is restricted to developing and transition economies. Table II provides summary statistics for the main variables used in this analysis.

The World Business Environment Survey (WBES) is a major cross-sectional survey of industrial and service enterprises conducted in developing and transition countries in 1999 by the World Bank and several other agencies. ${ }^{10}$ The main purpose of the WBES is to identify perceived constraints on enterprise performance and growth in developing and transition 
economies. The survey, therefore, has a large number of questions on how taxation and regulation, the performance of the financial sector, the institutional environment, and corruption affect business operations. In contrast, the survey includes little information on enterprise performance. In particular, it does not collect balance sheets or profit and loss statements from participating enterprises, although some information on assets, sales, employees, and enterprise growth is included. ${ }^{11}$ In addition, the survey provides some information on broad sector of operations, on ownership, on how enterprises financed investment, and on export performance.

The dependent variables in this study capture enterprises' perceptions about access to financing from the banking sector. As part of the WBES, enterprise managers were asked to assess how problematic several financing issues were to the operation and growth of their business on a four-point scale, with higher numbers indicating greater problems. ${ }^{12}$ In this study, we focus on the two measures most directly related to the formal banking sector - perceptions about interest rates and access to long-term loans.

Table III shows average ratings provided by enterprises of various types in the sample countries. Small enterprises generally rated access to long-term loans and access to non-bank equity as greater constraints than medium-sized or large enterprises. However, medium-sized enterprises generally rated interest rates as a bigger problem than small or large enterprises. In addition, state- and foreign-owned enterprises generally rated all three issues as lesser constraints than private domestic enterprises. These findings are not entirely surprising. State-owned enterprises might have better access to government financing and foreign-owned enterprises, which in developing countries are often owned by enterprises or individuals from developed countries, might have access to financing from their home countries. 
One potential concern about perception-related studies is that enterprise managers might have different perceptions about what constitutes a 'major' or 'minor' problem and, therefore, might rate equivalent obstacles differently. For example, a pessimistic manager might rate an obstacle as a 'major' problem, while a more optimistic manager might rate the same obstacle as only a 'moderate' or 'minor' obstacle. Since this introduces error into the dependent variable, this should not have a large effect on results so long as the error is not systematically correlated with the independent variables (i.e., mismeasurement of a dependent variable can generally be absorbed by the disturbance term in the regression). ${ }^{13}$ However, if enterprise managers' responses are systematically correlated with enterprise or country-level characteristics this could be a problem. ${ }^{14}$ In particular, estimates would be biased if enterprise managers' pessimism were systematically correlated with the degree of penetration by foreign banks or with other countrylevel variables. Thus, to provide a check on robustness, we also examine enterprise managers' perceptions about access to non-bank equity. Although foreign ownership in the banking sector might have a some small long-term influence on the development and performance of the nonbanking financial sector, the effect should be less pronounced than the impact foreign ownership has on the banking sector. If foreign ownership in the banking sector is as strongly related to perceptions about the non-banking financial sector as the banking sector, this might suggest evidence of either systematic bias or omitted variables.

In addition to questions about perceptions about the effect of financing on enterprise operations and growth, firms were also asked about how they financed fixed investment. Although they were not asked to provide estimates of the value of fixed investment over the previous year, they were asked what proportion was financed through funds from several different sources, including commercial banks. Table IV provides summary statistics for the 
share of investment financed through retained earnings, commercial banks, government subsidies and loans, and informal sources. Retained earnings were the most important source of financing for all types and sizes of enterprises. Commercial banks were the second most important source of financing for large and medium-sized enterprises (28.8 and 17.8 percent of investment respectively). In contrast, small enterprises financed considerably less investment through commercial banks (12.7 percent of investment) and, in fact, on average financed a greater proportion of investment through informal sources such as family and friends, and moneylenders. State-owned enterprises generally financed smaller proportions of investment through commercial banks (9.4 percent) than other enterprises, relying more on funds from the government (21.9 percent). This might explain why state-owned enterprises generally saw financial sector constraints as less problematic than privately owned enterprises (see Table III).

The second major source of data is from a survey of central banks conducted by the World Bank. ${ }^{15}$ Barth et al. (2001b) produced a survey consisting of 175 questions covering various aspects of banking sector development, which they sent to national regulatory and supervisory agencies in both developed and developing countries. They obtained at least partial responses from 107 countries, mostly between late 1998 and early 2000 (see footnote 7 in Barth et al., 2001b). In addition to questions about bank supervision and regulation, they also asked about the structure of bank ownership, including the share of assets held by banks that are over 50 percent foreign owned, the share of assets in state-owned banks, and the percent of deposits held by the 5 largest banks. These are the main banking sector variables from this source used in the empirical analysis. In addition to these variables, several variables related to the regulatory and supervisory environments are included in some model specifications to control for the quality of bank supervision and restrictions on entry. It is plausible that restrictions on entry 
might be correlated with foreign bank penetration (e.g., if supervisory authorities use restrictions on entry to restrict the presence of foreign banks) and with reduced access to credit (e.g., if entry restrictions reduce domestic competition). Similarly, the quality of supervision might also affect both foreign banks' entry decisions and sector performance. To control for this in the empirical analysis, two indices presented in Barth et al. (2001a) are included in some model specifications. ${ }^{16}$

Finally, the estimations include controls for the macroeconomic environment in which firms operate. In particular, we control for countries' GDP per capita, level of financial development (as measured by the ratio of M2 to GDP), inflation rate, and average growth rate. All of these variables come from the World Bank's World Development Indicators database. Other things being equal, access to credit could be better and foreign penetration could be higher in countries that are more financially developed and have better growth opportunities. We include the macro variables to be able to disentangle the independent effect of foreign penetration on access to credit.

\section{ECONOMETRIC METHODOLOGY}

Three of the dependent variables used in this analysis - enterprise managers' responses to questions about whether high interest rates, access to long-term loans, and to non-bank financing represent obstacles to enterprise operations and growth - are limited dependent variables. ${ }^{17}$ These variables can take four discrete values, in ascending order, corresponding to no obstacle, minor obstacle, moderate obstacle and major obstacle. Since the responses to the questions about perceptions are ordered, but are not actual count data, we estimate this model as an ordered 
response model. That is, we assume that the enterprise managers' underlying response model can be described by equation (1) below:

$$
\text { Obstacle }_{i j}=\beta_{1} X_{i j}+\beta_{2} C_{j}+u_{i j}
$$

where $X_{i j}$ are various characteristics of enterprise $i$ in country $j$ that affect the managers' perceptions about obstacles to growth, $C_{j}$ are characteristics of country $j$ that affect the managers' perceptions and $\mathrm{u}_{\mathrm{ij}}$ is a disturbance term. The manager classifies the obstacle as being in class ' $k$ ' (e.g., a moderate problem) if $\alpha_{k-1}<$ Obstacle $e_{i j}<\alpha_{k}$, where the $\alpha_{k}$ 's are a series of nuisance parameters that are estimated along with the coefficient vector (i.e., $\beta$ ). It is assumed that the disturbance term, which includes differences in individual managers' perceptions about what constitutes a 'major', 'minor', 'moderate' problem has a normal distribution. The model is estimated using standard maximum likelihood estimation. Positive coefficients on variables indicate that increases in that variable make enterprise managers more likely to rate the obstacle as a greater problem (i.e., it increases the likelihood that they rate the problem as a 'major' problem).

We assume that the share of fixed investment financed through commercial bank loans is a linear function of enterprise $\left(\mathrm{X}_{\mathrm{ij}}\right)$ and country $\left(\mathrm{C}_{\mathrm{j}}\right)$ level characteristics, as described in equation (2).

$$
\text { Financing }_{i j}=\beta_{1} X_{i j}+\beta_{2} C_{j}+u_{i j}(2)
$$

Since many enterprises did not finance any investment through loans from commercial banks in the year prior to the WBES, the share of fixed investment financed through commercial bank 
loans is bounded below by zero (and above by 100 percent). The model is therefore estimated as a standard two-limit Tobit model, assuming that the error term has a normal distribution.

\section{EMPIRICAL RESULTS}

Foreign Penetration in the Banking Sector. Controlling for macroeconomic conditions and other factors that might explain access to credit, we find that in countries where foreign penetration in the banking sector was higher (i.e., where foreign banks account for a greater share of banking sector assets), enterprises financed a greater share of investment through bank lending (see Table V, column 1). In addition to being statistically significant at a 10 percent level, the impact of foreign penetration in the banking sector appears large. In particular, increasing the share of bank assets held by foreign-owned banks by 1 percentage point raises the average share of investment financed through bank lending by 0.27 percentage points.

Consistent with this, enterprises rated high interest rates and access to long-term loans as lesser obstacles to enterprise operations and growth in countries with a larger degree of foreign penetration in the banking sector (see Table V, columns 2 and 3). ${ }^{18}$ In both cases the coefficient on foreign penetration is statistically significant at a one-percent level or higher. In contrast, foreign penetration is not significantly correlated with enterprises' perceptions concerning access to non-bank financing (see Table V, column 4). Since we would expect foreign penetration in the banking sector to impact the non-banking financial sector less than the banking sector, this provides some reassurance that the correlation between foreign penetration and enterprises' perceptions about the banking sector is not spurious.

Enterprise Size. As noted earlier, small (fewer than 50 employees) and medium-sized enterprises (between 50 and 200 employees) in developing countries tended to finance 
considerably less investment through the banking sector than large enterprises (more than 200 employees) did (see Table IV). ${ }^{19}$ This remains true even after controlling for other factors that might affect access to financing. On average, small and medium-sized enterprises financed 22.1 percentage points and 8.0 percentage points less of their fixed investment through bank loans than similar large enterprises (see Table V, column 1). In both cases the difference is statistically significant at least at the 10 percent level. Results are similar after allowing foreign bank ownership to affect small, medium-sized, and large enterprises differently (see Table VI, column 1), after dropping the controls for enterprise performance (see, Table VII column 1) and after accounting for differences in bank regulation and supervision (see Table VII, column 4).

Small and medium-sized enterprises also generally rated high interest rates, access to long-term loans, and access to non-bank financing as greater constraints on enterprise operations and growth than large enterprises. These differences are statistically significant in several cases. However, there is no clear pattern when comparing small and medium-sized enterprises. After controlling for other factors that might affect enterprise performance, medium-sized enterprises rated high interest rates as a greater constraint than small (or large) enterprises, while small enterprises rated access to non-bank financing and long-term loans as greater constraints than medium enterprises.

Interaction between Enterprise Size and Foreign Penetration in the Banking Sector. Although on average enterprises saw interest rates and access to long-term loans as lesser constraints and financed greater shares of investment through commercial banks in countries where foreign bank penetration was greater, it is still possible that the benefits primarily go to medium or large enterprises. To test whether this is the case, interaction terms between enterprise size and the extent of foreign bank penetration are included in the regressions in Table 
$\mathrm{VI}^{20}$ When we include these interaction terms in the regression for the share of investment financed through commercial bank loans, the coefficient on foreign penetration is larger for large enterprises than it is for medium or small enterprises (see Table VI, column 1). Further, the coefficient on the interaction term for small enterprises is statistically insignificant at conventional significance levels. The point estimates of the coefficients suggest that a 1 percentage point increase in foreign bank assets raises the share of investment financed through commercial bank loans by $0.23,0.26$, and 0.35 percentage points for small, medium, and large enterprises, respectively.

The results are similar for the measures of the obstacles to enterprise operations and growth imposed by high interest rates and access to long-term financing. Increased foreign penetration generally affects the perceptions of small and medium enterprise managers less than managers of large enterprises. Increasing foreign bank penetration from 5.1 percent (foreign bank penetration at the level of the $20^{\text {th }}$ percentile of countries in the sample) to 50.9 percent $\left(80^{\text {th }}\right.$ percentile) decreases the probability that the average enterprise manager would rate interest rates and access to long-term loans as a major constraint by 9.6 and 23.7 percentage points, respectively (see Table VIII). ${ }^{21}$ However, the impact is smaller for small enterprises (8.1 and 23.6 percentage points respectively) than for large enterprises (12.3 and 25.1 percentage points).

Although these results might suggest that large (and medium-sized) enterprises benefit more than small enterprises from foreign penetration in the banking sector, it is important to note two things. First, the null hypothesis that foreign penetration affects all enterprises equally cannot be rejected in any of the three equations. ${ }^{22}$ Second, even if foreign penetration is more favorable for large enterprises, there is strong evidence that it also benefits small and mediumsized enterprises. The empirical results suggest that both small and medium-sized enterprises 
rate access to long-term loans and high interest rates as lesser obstacles and that medium-sized enterprises finance more investment through commercial bank loans in countries with higher levels of foreign penetration.

Other Banking Sector Variables. In addition to foreign bank penetration, the analysis includes two extra variables to control for other differences in the structure of banking sectors across countries: the share of assets in the 5 largest banks, which is used as a proxy for sector concentration, and the share of assets in state-owned banks. Concentration might affect lending if it affects the level of competition in the banking sector. For example, banks in concentrated markets might find it easier to collude, raising interest rates, and restricting access to long-term loans, or large banks might have different lending strategies from smaller banks. Similarly, state-owned banks might also behave differently than private banks. ${ }^{23}$

In all regressions, the coefficients on government ownership are statistically insignificant. The coefficients on sector concentration are statistically significant and positive in the regression for enterprises' perceptions about access to long-term loans, suggesting that concentration tends to make access to such financing more difficult. Increasing the share of assets in the five largest banks from the value for the $20^{\text {th }}$ percentile $\left(51.2\right.$ percent) to the value for the $80^{\text {th }}$ percentile (81.2 percent) raises the estimated average probability that an enterprise would rate access to long-term loans as a major problem from 29.7 percent to 46.3 percent (see Table IX). ${ }^{24}$

Also consistent with the observation that increased concentration makes access to longterm loans more difficult, the coefficient on concentration is negative and significant in the regression for the share of investment financed through commercial bank loans. ${ }^{25}$ Based upon the coefficients in Table $\mathrm{V}$, a one percentage point increase in the share of assets in the 5 largest 
banks would decrease the share of investment financed through commercial bank loans by 0.3 percentage points. This result, however, is not robust to the exclusion of the two measures of enterprise performance (see Table VII, Column 1).

Enterprise Characteristics. Both state- and foreign-owned enterprises rated interest rates and access to long-term loans as lesser constraints than similar private domestic enterprises (see Table V). State-owned enterprises also financed smaller shares of investment through bank loans than private enterprises (see Table V), even after controlling for other factors that might affect financing. A 1 percentage point increase in government ownership reduces the share of investment financed through bank loans by 0.3 percentage points. Although state-owned enterprises might finance less investment through bank loans because they find it more difficult to raise financing from commercial banks, the evidence is also consistent with the possibility that that state-owned enterprises might rely less on bank loans because they have access to other sources of financing. As noted earlier, state-owned enterprises financed 21 percent of investment with government funds (see Table IV). Consequently, since they have access to state financing, it is not surprising that they rate interest rates and access to long-term loans as less severe constraints than private enterprises do.

In contrast to state-owned enterprises, foreign-owned enterprises financed higher shares of investment through commercial banks than private domestic enterprises (see Table IV), although the difference becomes statistically insignificant after controlling for other factors (e.g., size) that might affect bank borrowing (see Table V). One plausible reason why foreign-owned enterprises might rate access to financing and high interest rates as lesser constraints than private domestic enterprises might be because the former have access to banks in their home countries. However, domestic enterprises that have operations outside of their home country did not 
generally rate interest rates or access to long-term loans as lesser constraints than enterprises that did not operate outside of their home market (see Table V). ${ }^{26}$

Firm Performance. As noted previously, the WBES does not provide detailed information on enterprise performance and, therefore, it is difficult to test the link between enterprise performance and financing as an obstacle to enterprise operations and growth using this data set. Although two of the performance-related measures that are included in the analysis, sales growth and export growth, might be endogenous in the equation for the share of investment financed through bank loans (i.e., if access to bank loans allows faster growth), results are similar when these variables are omitted (compare Table VI and Table VII). In practice, neither of these variables appears to strongly affect perceptions about financing (see Table V), although enterprises with faster sales growth did finance more investment through bank loans than similar enterprises that were growing more slowly. Exporters also tended to finance more investment through commercial bank loans. It is possible that this is because exports also serve as a proxy for overall firm performance - several studies have found that exporters are more efficient than similar non-exporters. ${ }^{27}$

Macroeconomic Control Variables. In addition to the enterprise level controls, several variables are also included in the estimation to account for macroeconomic factors that might affect access to loans or interest rates. ${ }^{28}$ In general, the macroeconomic variables have the expected signs and are often, but not always, statistically significant. Table IX provides estimates of the magnitude of the effect of changes in the macroeconomic variables on enterprise performance. Enterprises in countries with higher per capita income report that high interest rates, access to long-term loans, and access to non-bank equity are lesser constraints than similar enterprises in countries with lower per capita income (see Table V). Similarly, enterprises in 
countries that are growing more rapidly also report that all three aspects of financing are lesser constraints than enterprises in slower growing economies. However, these variables do not have a statistically significant effect on the share of investment financed through bank loans.

Enterprises in countries with better-developed financial markets, as measured by the ratio of money and quasi-money to GDP, appear to see all aspects of financing as lesser constraints on enterprise performance than firms in countries with less developed financial markets (see Table V). ${ }^{29}$ However, the coefficients are not always statistically significant. Further, financial market development also appears to be correlated with the share of investment financed through bank loans in developing and transition economies. A 1 percentage point increase in the ratio of M2 to GDP raises the share of investment financed through bank loans by 0.31 percentage points. Finally, although enterprises in countries with higher rates of inflation tended to report that high interest rates were a greater constraint on enterprise operations and growth, they did not indicate that access to long-term loans was a greater problem than similar enterprises in countries where inflation was lower. One slightly anomalous result is that enterprises in countries with high rates of inflation generally rated access to non-bank financing as a lesser constraint than enterprises in countries where inflation was lower. In general, these results are robust to the inclusion of the interaction terms (see Table VI) and the exclusion of the enterprise performance variables (see Table VII).

Regulatory Variables. The previous results suggest that enterprises finance more investment through bank loans and feel less constrained by high interest rates and access to longterm loans in countries with high foreign bank penetration. However, it is plausible that foreign bank penetration might be affected by the quality of regulation and supervision or by ease of entry, which might also affect the perceptions and behavior of enterprises. For example, foreign 
banks might find it easier to enter banking sectors of countries with relatively liberal entry requirements. However, these same countries might also have more competitive domestic banking sectors, which might, in turn, lead to favorable financing outcomes for enterprises. To control for the possibility that the quality of supervision or entry restrictions might affect acsess to loans or interest rates, one variable representing restrictions on entry and another for supervisory power are added to the base regressions (see Table VII, columns 4-6). Although the coefficients on the regulatory variables are sometimes statistically insignificant, it appears that enterprises tend to finance less investment through bank loans in countries where bank entry is more restricted. Also, enterprises rate access to long-term loans as lesser constraints on operations and growth in countries where supervisors have greater power. The first result would be consistent with the hypothesis that competition might be greater in countries with fewer entry restrictions.

Including the additional regulatory variables does not appear to affect other results greatly, although some of the macroeconomic variables become statistically insignificant. In particular, the coefficients on foreign penetration tend to become slightly larger in absolute value and remain statistically significant for enterprises of all sizes. One noticeable change is that the coefficient on concentration becomes statistically significant in the regression for constraints imposed by high interest rates, in addition to being significant in the regression for constraints imposed by access to long-term loans. This provides further evidence that market concentration in the banking sector might impose a constraint upon enterprises in that country. ${ }^{30}$

Cross-Country Analysis. As a check for robustness, in addition to the enterprise-level regressions discussed above, we also present results from cross-country regressions for enterprises of different sizes. Since there are very few large enterprises in many countries in our 
sample - often fewer than ten - medium and large enterprises are pooled together when calculating averages. The dependent variables are averaged over all enterprises of that type (e.g., small enterprises) in each country. These average scores are then regressed on the banking sector and the macroeconomic variables. ${ }^{31}$ Despite the low number of observations, the results are broadly similar to those from the enterprise level analysis, although significance levels tend to be lower (Table X). Both small and medium-sized and large enterprises rated access to longterm loans as lesser constraints in countries with higher levels of foreign bank penetration. In addition, medium and large enterprises rated interest rates as lesser constraints in countries with higher levels of foreign bank penetration and tended to finance greater proportions of investment through bank loans. Although the coefficients on foreign bank penetration in the regressions for interest rates and percent of investment financed through bank loans have similar signs for small enterprises, they are statistically insignificant. The coefficients on the other macro and banking sector control variables generally have the same signs as in the enterprise-level regressions, although they are mostly statistically insignificant.

\section{CONCLUSION}

Policymakers in developing countries are often concerned that even if increased penetration by foreign banks improves sector efficiency, sector stability and competition, it might have some harmful side effects. In particular, it has been suggested that foreign entry might result in less credit to some sectors of the economy, particularly small and medium-sized enterprises. Combining responses from a survey of over 4,000 enterprises in 38 developing and transition economies with data on the degree of foreign bank penetration in those countries, this paper investigates the impact of foreign bank entry on enterprises' access to credit. 
Overall, the empirical results strongly support the assertion that foreign bank penetration improves firms' access to credit. Enterprises in countries with high levels of foreign bank penetration tended to rate interest rates and access to long-term loans as lesser constraints on enterprise operations and growth than enterprises in countries with less foreign penetration. Further, the benefits of high levels of foreign bank penetration do not appear to accrue only to large enterprises. Although some evidence suggests that entry by foreign banks benefits large enterprises more than small ones, there is strong evidence that even small enterprises benefit in some ways and there is no evidence that they are harmed by foreign bank entry.

At first sight, this result might seem inconsistent with developing country case studies that find that foreign banks lend smaller shares of their portfolios to small and medium-sized enterprises than similar domestic banks. There are a number of reasons why this is not necessarily so. First, cross-country evidence suggests that increased foreign bank entry is associated with lower interest margins and overhead costs. If improved efficiency results in an expansion in total lending, the amount of lending to SMEs might increase even if the share of lending to them falls. Second, increased foreign bank participation might cause domestic banks to modify their behavior. In particular, foreign competition for larger clients might force existing domestic banks to seek new market niches, which could benefit small borrowers in the medium term. The findings from this study are broadly consistent with these explanations: although small enterprises appear to benefit from higher penetration by foreign banks, large enterprises appear to gain more. 


\section{REFERENCES}

Avery, Robert B. and Katherine A. Samolyk, 2000, Bank Consolidation and the Provision of Banking Services: The Case of Small Commercial Loans, Federal Deposit Insurance Corporation working paper.

Barajas, Adolfo, Roberto Steiner, and Natalia Salazar, 2000, Foreign Investment in Colombia's Financial Sector, in Claessens, S. and Marion Jansen, eds.: The Internationalization of Financial Services: Issues and Lessons for Developing Countries (Kluwer Academic Press, Boston, MA).

Barth, James R., Gerard Caprio, and Ross Levine, 2001a, Bank Regulation and Supervision: What Works Best? Mimeo, World Bank, Washington DC.

Barth, James R., Gerard Caprio, and Ross Levine, 2001b, The Regulation and Supervision of Banks Around the World: A New Database, Policy Research Working Paper \#2588, World Bank, Washington DC.

Barth, James, Gerard Caprio, and Ross Levine, 2001c, Banking Systems Around the Globe: Do Regulation and Ownership Affect Performance and Stability? Forthcoming in Mishkin, Frederic ed.:, Prudential Regulation and Supervision: What Works and What Doesn't, (National Bureau of Economic Research, Boston, MA).

Berger, Allen N. and Gregory F. Udell, 1995, Relationship Lending and Lines of Credit in Small Firm finance, Journal of Business, 68: 351-382.

Berger, Allen N. and Gregory F. Udell, 1996, Universal Banking and the Future of Small Business Lending, in Anthony Saunders and Ingo Walter eds.:, Financial System design: The Case for Universal Banking, (Irwin Publishing, Burr Ridge, IL.)

Berger, Allen N., Anil K. Kashyap, and Joseph M. Scalise, 1995, The Transformation of the U.S. Banking Industry: What a Long Strange Trip It's Been, Brookings Papers on Economic Activity 2, 55-218.

Berger, Allen N., Anthony Saunders, Joseph M. Scalise, and Gregory F. Udell, 1998, The Effects of Bank Mergers and Acquisitions on Small Business Lending, Journal of Financial Economics, 50(2), 187-229.

Berger, Allen N., Leora F. Klapper, and Gregory F. Udell, 2000a, The Ability of Banks to Lend to Informationally Opaque Small Businesses, Mimeo, World Bank, Washington DC.

Berger, Allen N., Robert DeYoung, Hesna Genay, and Gregory F. Udell, 2000b, Globalization of Financial Institutions: Evidence from Cross-Border Banking Performance, Brookings Papers on Economic Activity 2, 23-158. 
Bonin, John and István Abel, 2000, Retail Banking in Hungary: A Foreign Affair? Mimeo, Wesleyan University, Middletown, CT. Prepared as background paper for, World Bank, World Development Report 2002: Building Institutions for Markets.

Chang, C. Edward, Iftekhar Hasan, and William C. Hunter, 1998, Efficiency of Multinational Banks: An Empirical Investigation, Applied Financial Economics 8(6), 1-8.

Cho, Kang Rae, Suresh Krishnan, and Douglas Nigh, 1987, The State of Foreign Banking Presence in the United States, International Journal of Bank Marketing 5(2), 59-75.

Claessens, Stijn and Marion Jansen (eds.), 2000, The Internationalization of Financial Services: Issues and Lessons for Developing Countries, (Kluwer Academic Press, Boston, MA).

Claessens, Stijn, Asli Demirgüç-Kunt, and Harry Huizinga, 2000, The Role of Foreign Banks in Domestic Banking Systems, in: Claessens, Stijn and Marion Jansen, eds.: The Internationalization of Financial Services: Issues and Lessons for Developing Countries, (Kluwer Academic Press, Boston, MA).

Claessens, Stijn, Asli Demirgüç-Kunt, and Harry Huizinga, 2001, How Does Foreign Entry Affect the Domestic Banking Market?, Journal of Banking and Finance 25 (5), 891-911.

Clarke, George R.G., and Robert Cull, 1999, Why Privatize? The Case of Argentina's Public Provincial Banks, World Development 27 (5), 867-888.

Clarke, George R.G. and Robert Cull, forthcoming, Political and Economic Determinants of the Likelihood of Privatizing Argentine Public Banks, Journal of Law and Economics.

Clarke, George, Robert Cull, Laura D'Amato, and Andrea Molinari, 2000, On the Kindness of Strangers? The Impact of Foreign Entry on Domestic Banks in Argentina, in: Claessens, Stijn and Marion Jansen, eds.: The Internationalization of Financial Services: Issues and Lessons for Developing Countries, (Kluwer Academic Press, Boston MA).

Clarke, George, Robert Cull, Maria Soledad Martinez Peria, and Susana M. Sánchez, 2001, "Bank Lending to Small Businesses in Latin America: Does Bank Origin Matter?" Mimeo, World Bank, Washington DC.

Dages, Gerard, Linda Goldberg, and Daniel Kinney, 2000, Federal Reserve Bank of New York Economic Policy Review, September.

Demirgüç-Kunt, Asli and Harry Huizinga, 1999, Determinants of Commercial Bank Interest Margins and Profitability: Some International Evidence, World Bank Economic Review, 13(2): 379-408.

Demirgüç-Kunt, Asli and Ross Levine, 2000, Bank Concentration: Cross-Country Evidence, World Bank mimeo. 
Demirgüç-Kunt, Asli, Ross Levine, and Hong G. Min, 1998, Opening to Foreign Banks: Issues of Stability, Efficiency and Growth, in Proceedings of the Bank of Korea Conference on the Implications of Globalization of World Financial Markets.

DeYoung, Robert and Daniel E. Nolle, 1996, Foreign-owned banks in the United States: Earning Market Share of Buying it?, Journal of Money, Credit, and Banking, 28(4), 622-36.

Escudé Guillermo, Tamara Burdisso, Marcelo Catena, Laura D'Amato, George Mc Candless, and Tomás Murphy, 2001, "Las MIPyMES y el Mercado de Crédito en la Argentina," Documento de Trabajo Nro. 15, Banco Central de la República Argentina,

Focarelli, Dario and Alberto Pozzolo, 2000, The Determinants of Cross-Border Shareholding: An Analysis with Bank-Level Data from OECD Countries, Paper presented at the Federal Reserve Bank of Chicago Bank Structure Conference, May.

Goldberg, Lawrence G., 1992, The Competitive Impact of Foreign Commercial Banks in the United States, in R. Alton Gilbert, ed.:, The Changing Market in Financial Services, Proceedings of the Fifteenth Annual Economic Policy Conference of the Federal Reserve Bank of St. Louis, (Kluwer Academic, Norwell, MA).

Goldberg, Linda B., 2001, "When is U.S. Bank Lending to Emerging Markets Volatile?," Federal Reserve Bank of New York, Mimeo.

Greene, William, 2000, Econometric Analysis, $4^{\text {th }}$ Edition, (Prentice Hall, Upper Saddle River, NJ.)

Hasan, Iftekhar and William Curt Hunter, 1996, Efficiency of Japanese Multinational Banks in the United States, in Andrew H. Chen, ed.:, Research in Finance, Volume 14, (Greenwich, CT and London: JAI Press).

Hellman, Joel, Geraint Jones, Daniel Kaufmann, and Mark Schankerman, 2000, Measuring Governance and State Capture: The Role of Bureaucrats and Firms in Shaping the Business Environment, European Bank for Reconstruction and Development Working Paper \# 51, London, UK.

Jenkins, Hatice, 2000, Commercial Bank Behavior in Micro and Small Enterprise Finance, Development Discussion Paper \# 741, Harvard Institute for International Development, Harvard University, Boston, MA.

Keeton, William R., 1995, Multi-Office Bank Lending to Small Businesses: Some New Evidence, Federal Reserve Bank of Kansas City Economic Review 80(2), 45-57.

Levonian, Mark and J. Soller, 1995, Small Banks, Small Loans, Small Business, Mimeo, Federal Reserve Bank of San Francisco, San Francisco, CA.

Mahajan, Arvind, Nanda Rangan, and Ashgar Zardkoohi, 1996, Cost Structures in Multinational and Domestic Banking, Journal of Banking and Finance 20(2): 238-306. 
Mester, Loretta J., 1997, What's the Point of Credit Scoring ?, Federal Reserve Bank of Philadelphia Business Review, Sept.-Oct.: 3-16.

Miller, Stewart R. and Arvind Parkhe, 1999, Home-Country Environment as a Source of International Competitiveness: An Analysis of the Global Banking Industry, Michigan State University, Mimeo.

Parkhe, Arvind and Stewart R. Miller, 1999, Is There a Liability of Foreignness in Global Banking? An Empirical Test of U.S. Banks' X-Efficiency, Michigan State University, Mimeo.

Peek, Joe and Eric S. Rosengren, 1996, Small Business Credit Availability: How Important is Size of Lender?, in Anthony Saunders and Ingo Walter, eds., Financial System Design: The Case for Universal Banking, (Irwin Publishing, Burr Ridge, IL.)

Petersen, Mitchell A. and Raghuram G. Rajan, 2000, Does Distance Still Matter? The Information Revolution in Small Business Lending, mimeo.

Strahan, Philip E. and James P. Weston, 1996, Small Business Lending and Bank Consolidation: Is There Cause for Concern?, Federal Reserve Bank of New York Current Issues in Economics and Finance 2, 1-6.

World Bank, 2001, World Development Indicators, World Bank, Washington DC. 
Table I: Countries Included in the Analysis.

\begin{tabular}{|ccc|}
\hline & Country List & \\
\hline Argentina & Guatemala & Poland \\
Bangladesh & Honduras & Portugal \\
Belarus & India & Rumania \\
Bolivia & Indonesia & Russia \\
Botswana & Lithuania & Senegal \\
Brazil & Malawi & Slovenia \\
Cambodia & Malaysia & South \\
Chile & Mexico & Thailand \\
Croatia & Moldova & Trinidad \\
Czech & Nigeria & Turkey \\
Egypt & Panama & Venezuela \\
Estonia & Peru & Zambia \\
Ghana & Philippines & \\
\hline
\end{tabular}


Table II: Sample Means for Independent Variables.

\begin{tabular}{|c|c|c|c|c|}
\hline Variable & Description & Source & Mean & $\begin{array}{c}\text { Standard } \\
\text { Dev. }\end{array}$ \\
\hline \multicolumn{5}{|l|}{ Foreign Banks } \\
\hline Assets of Foreign Banks & Percent of total in 1999 & $\begin{array}{l}\text { Barth et al. } \\
\quad(2001)\end{array}$ & 25.79 & 26.41 \\
\hline \multicolumn{5}{|l|}{ Banking Sector } \\
\hline Assets of 5 Largest Banks & Percent of total in 1999 & $\begin{array}{l}\text { Barth et al. } \\
\quad(2001)\end{array}$ & 69.19 & 14.95 \\
\hline Assets of State-Owned Banks & Percent of total in 1999 & $\begin{array}{l}\text { Barth et al. } \\
\quad(2001)\end{array}$ & 37.50 & 24.90 \\
\hline \multicolumn{5}{|l|}{ Enterprise Characteristics } \\
\hline $\begin{array}{l}\text { Small Enterprise (Fewer than } 50 \\
\text { employees) }\end{array}$ & Dummy variable & WBES & 0.385 & 0.487 \\
\hline $\begin{array}{l}\text { Medium Enterprise (Between } 50 \text { and } 200 \\
\text { employees) }\end{array}$ & Dummy variable & WBES & 0.437 & 0.496 \\
\hline State Ownership & Percent of state-owned & WBES & 8.761 & 25.713 \\
\hline Foreign Ownership & $\begin{array}{l}\text { Percent of foreign- } \\
\text { owned }\end{array}$ & WBES & 11.88 & 28.9 \\
\hline Sales Growth & 1996 to 1998 & WBES & 14.63 & 59.26 \\
\hline Exports Growth & 1996 to 1998 & WBES & 4.28 & 37.78 \\
\hline Enterprise Exports & Percent of sales & WBES & 17.09 & 30.01 \\
\hline Operations outside of home country & Dummy variable & & 0.161 & 0.368 \\
\hline \multicolumn{5}{|l|}{ Macroeconomic Factors } \\
\hline Per Capita GDP & Natural $\log$ in 1998 & WDI & 8.53 & 0.74 \\
\hline M2 (Quasi-money and money) & Percent of GDP in 1998 & WDI & 35.75 & 23.04 \\
\hline Inflation & In 1998 & WDI & 18.04 & 20.7 \\
\hline GDP growth & Average 1996-98 & WDI & 2.39 & 3.51 \\
\hline \multicolumn{5}{|l|}{ Regional Dummies } \\
\hline Caribbean & Dummy variable & WBES & 0.014 & 0.119 \\
\hline Central and Eastern Europe & Dummy variable & WBES & 0.286 & 0.452 \\
\hline Commonwealth of Independent States & Dummy variable & WBES & 0.230 & 0.42 \\
\hline East Asia and China & Dummy variable & WBES & 0.146 & 0.353 \\
\hline Latin America & Dummy variable & WBES & 0.094 & 0.292 \\
\hline Middle East and North Africa & Dummy variable & WBES & 0.062 & 0.241 \\
\hline South Asia & Dummy variable & WBES & 0.042 & 0.200 \\
\hline Sub-Saharan Africa & Dummy variable & WBES & 0.125 & 0.331 \\
\hline \multicolumn{5}{|l|}{ Sector of Operations } \\
\hline Manufacturing & Dummy variable & WBES & 0.403 & $0.49]$ \\
\hline Services & Dummy variable & WBES & 0.376 & 0.484 \\
\hline Other & Dummy variable & WBES & 0.033 & 0.178 \\
\hline Agriculture & Dummy variable & WBES & 0.098 & 0.298 \\
\hline Construction & Dummy variable & WBES & 0.091 & 0.287 \\
\hline
\end{tabular}

Note: WBES indicates The World Business Environment Survey (WBES) 02000 The World Bank Group and WDI refers to the World Bank's World Development Indicators. Averages are calculated for the sample from the regression shown in Column : of Table V. 
Table III: Average Financial Sector Constraints by Enterprise Type

\begin{tabular}{|c|c|c|c|c|c|c|}
\hline & All & $\begin{array}{c}\text { State- } \\
\text { Owned a }\end{array}$ & $\begin{array}{l}\text { Foreign } \\
\text { Owned }^{\mathrm{a}}\end{array}$ & Small $^{b}$ & $\begin{array}{l}\text { Medium- } \\
\text { Sized }^{\mathrm{b}}\end{array}$ & Large \\
\hline Number of Observations & 2948 & 251 & 333 & 1134 & 1288 & 526 \\
\hline High Interest Rates & 3.32 & 3.18 & 3.12 & 3.26 & 3.38 & 3.27 \\
\hline Access to Long-Term Loans & 2.65 & 2.37 & 2.29 & 2.71 & 2.61 & 2.58 \\
\hline Access to Non-Bank Equity/Partners & 2.05 & 1.95 & 1.72 & 2.11 & 2.08 & 1.89 \\
\hline
\end{tabular}

Data Source: The World Business Environment Survey (WBES) 02000 The World Bank Group

Note: Averages are calculated using the observations included in regressions in Table V. Observations are for high interest rates - fewer observations were available for the other two measures. Averages are simple averages of ratings given by enterprise managers in answer to questions such as: "Using [a four-point scale], can you please tell in turn how problematic are these different financing issues for the operation and growth of your business." The scores are as follows: 1 indicates no obstacle; 2 indicates a minor obstacle; 3 indicates a moderate obstacle; and 4 indicates a major obstacle."

a State- and Foreign-owned implies that over 50 percent of the enterprise is owned by that source. ${ }^{b}$ Small enterprises have fewer than 50 employees, medium-sized enterprises between 50 and 200, and large enterprises have over 200.

Table IV: Share (\%) of Investment Financed through Different Sources by Enterprise Type

\begin{tabular}{|c|c|c|c|c|c|c|}
\hline & All & $\begin{array}{c}\text { State- } \\
\text { Owned }\end{array}$ & $\begin{array}{l}\text { Foreign } \\
\text { Owned }\end{array}$ & Small $^{b}$ & $\begin{array}{c}\text { Medium- } \\
\text { Sized }^{b}\end{array}$ & Large $^{b}$ \\
\hline Number of Observations & 2221 & 205 & 172 & 890 & 1020 & 311 \\
\hline Retained Earnings & 52.9 & 51.4 & 47.6 & 53.4 & 55.1 & 44.6 \\
\hline Commercial Banks & 17.3 & 9.4 & 29.6 & 12.7 & 17.8 & 28.8 \\
\hline Government & 3.6 & 21.9 & 0.2 & 0.7 & 5.6 & 5.6 \\
\hline Informal Sources ${ }^{c}$ & 7.8 & 0.9 & 1.7 & 15.6 & 3.0 & 1.1 \\
\hline Other Sources ${ }^{\mathrm{d}}$ & 18.4 & 16.4 & 21.0 & 17.7 & 18.4 & 20.0 \\
\hline
\end{tabular}

Data Source: The World Business Environment Survey (WBES) C2000 The World Bank Group.

Note: Average are calculated based on the observations included in regressions in Table V.

${ }^{a}$ State- and Foreign-owned implies that over 50 percent of the enterprise is owned by that group. ${ }^{b}$ Small enterprises have fewer than 50 employees, medium-sized enterprises between 50 and 200 , and large enterprises have over $200 .^{c}$ Informal sources include family and friends, money lenders, and other traditional or informal sources. 'Other sources include supplier credit, leasing arrangements, equity and sale of stock, and other unspecified sources. 
Table V: Effect of Foreign Bank Penetration on Enterprises' Access to Financing

\begin{tabular}{|c|c|c|c|c|}
\hline & (1) & (2) & (3) & (4) \\
\hline & Tobit & $\begin{array}{l}\text { Ordered } \\
\text { Probit }\end{array}$ & $\begin{array}{l}\text { Ordered } \\
\text { Probit }\end{array}$ & $\begin{array}{l}\text { Ordered } \\
\text { Probit }\end{array}$ \\
\hline $\begin{array}{l}\text { Obstacle } \\
\text { (High values indicate greater obstacle) }\end{array}$ & $\begin{array}{c}\% \text { of } \\
\text { Investment } \\
\text { Financed } \\
\text { through Bank } \\
\text { Loans }\end{array}$ & $\begin{array}{l}\text { High Interest } \\
\text { Rates }\end{array}$ & $\begin{array}{l}\text { Access to } \\
\text { Long-Term } \\
\text { Loans }\end{array}$ & $\begin{array}{l}\text { Access to } \\
\text { Non-Bank } \\
\text { Financing }\end{array}$ \\
\hline Number of Observations & 2221 & 2948 & 2116 & 2231 \\
\hline Regional Dummies $^{\text {a }}$ & Yes & Yes & Yes & Yes \\
\hline Sector of Operations ${ }^{6}$ & Yes & Yes & Yes & Yes \\
\hline \multicolumn{5}{|l|}{ Foreign Banks } \\
\hline $\begin{array}{l}\text { Assets of Foreign Banks } \\
(\% \text { of total in 1999) }\end{array}$ & $\begin{array}{c}0.2683^{*} \\
(1.89) \\
\end{array}$ & $\begin{array}{c}-0.0060 * * * \\
(-3.63) \\
\end{array}$ & $\begin{array}{c}-0.0153^{* * *} \\
(-5.97)\end{array}$ & $\begin{array}{c}-0.0024 \\
(-1.42)\end{array}$ \\
\hline \multicolumn{5}{|l|}{ Banking Sector } \\
\hline $\begin{array}{l}\text { Assets of } 5 \text { Largest Banks } \\
(\% \text { of total in 1999) }\end{array}$ & $\begin{array}{c}-0.3002^{* *} \\
(-1.99)\end{array}$ & $\begin{array}{l}0.0024 \\
(1.04)\end{array}$ & $\begin{array}{c}0.0160 * * * \\
(5.53)\end{array}$ & $\begin{array}{l}0.0039 \\
(1.52)\end{array}$ \\
\hline $\begin{array}{l}\text { Assets of State-Owned Banks } \\
(\% \text { of total in 1999) }\end{array}$ & $\begin{array}{c}0.0840 \\
(0.62) \\
\end{array}$ & $\begin{array}{l}-0.0010 \\
(-0.56) \\
\end{array}$ & $\begin{array}{c}0.0008 \\
(0.34)\end{array}$ & $\begin{array}{r}-0.0007 \\
(-0.39)\end{array}$ \\
\hline \multicolumn{5}{|l|}{ Enterprise Characteristics } \\
\hline $\begin{array}{l}\text { Small Enterprise } \\
\text { (Dummy Variable) }\end{array}$ & $\begin{array}{c}-22.1338 * * * \\
(-4.52)\end{array}$ & $\begin{array}{l}0.0617 \\
(0.82)\end{array}$ & $\begin{array}{c}0.1825^{* *} \\
(1.99)\end{array}$ & $\begin{array}{l}0.1951^{* *} \\
(2.42)\end{array}$ \\
\hline $\begin{array}{l}\text { Medium Enterprise } \\
\text { (Dummy Variable) }\end{array}$ & $\begin{array}{c}-8.0146^{*} \\
(-1.90)\end{array}$ & $\begin{array}{l}0.1579 * * \\
(2.41)\end{array}$ & $\begin{array}{l}0.0297 \\
(0.37)\end{array}$ & $\begin{array}{l}0.1688^{* *} \\
(2.45)\end{array}$ \\
\hline $\begin{array}{l}\text { State Ownership } \\
(\% \text { of enterprise state-owned })\end{array}$ & $\begin{array}{c}-0.2805^{* * *} \\
(-4.44)\end{array}$ & $\begin{array}{c}-0.0036 * * * \\
(-3.87)\end{array}$ & $\begin{array}{c}-0.0040 * * * \\
(-3.85)\end{array}$ & $\begin{array}{l}-0.0014 \\
(-1.36)\end{array}$ \\
\hline $\begin{array}{l}\text { Foreign Ownership } \\
(\% \text { of enterprise foreign-owned })\end{array}$ & $\begin{array}{l}0.0135 \\
(0.23)\end{array}$ & $\begin{array}{c}-0.0026^{* * *} \\
(-3.01)\end{array}$ & $\begin{array}{c}-0.0045^{* * *} \\
(-4.00)\end{array}$ & $\begin{array}{c}-0.0049 * * * \\
(-5.17)\end{array}$ \\
\hline $\begin{array}{l}\text { Sales Growth } \\
(1996 \text { to } 1998)\end{array}$ & $\begin{array}{c}0.0360^{*} \\
(1.66)\end{array}$ & $\begin{array}{c}-0.0009^{* *} \\
(-2.40)\end{array}$ & $\begin{array}{c}0.0001 \\
(0.16) \\
\end{array}$ & $\begin{array}{l}0.0004 \\
(0.93)\end{array}$ \\
\hline $\begin{array}{l}\text { Exports Growth } \\
(1996 \text { to } 1998)\end{array}$ & $\begin{array}{l}-0.0022 \\
(-0.06)\end{array}$ & $\begin{array}{c}-0.0002 \\
(-0.31)\end{array}$ & $\begin{array}{l}0.0006 \\
(0.82)\end{array}$ & $\begin{array}{l}0.0010 \\
(1.55)\end{array}$ \\
\hline $\begin{array}{l}\text { Enterprise Exports } \\
\text { (\% of sales) }\end{array}$ & $\begin{array}{l}0.0971 \\
(1.87)\end{array}$ & $\begin{array}{l}-0.0010 \\
(-1.19)\end{array}$ & $\begin{array}{c}0.0020^{*} \\
(1.94)\end{array}$ & $\begin{array}{l}0.0022^{* *} \\
(2.36)\end{array}$ \\
\hline $\begin{array}{l}\text { Operations outside of home country } \\
\text { (Dummy variable) }\end{array}$ & $\begin{array}{l}-5.3026 \\
(-1.19)\end{array}$ & $\begin{array}{l}-0.0513 \\
(-0.75)\end{array}$ & $\begin{array}{l}0.0020 \\
(0.02)\end{array}$ & $\begin{array}{l}-0.0335 \\
(-0.47)\end{array}$ \\
\hline \multicolumn{5}{|l|}{ Macroeconomic Factors } \\
\hline $\begin{array}{l}\text { Per Capita GDP } \\
\text { (Natural Log, 1998) }\end{array}$ & $\begin{array}{l}1.4546 \\
(0.27)\end{array}$ & $\begin{array}{c}-0.2684 * * * \\
(-5.09)\end{array}$ & $\begin{array}{c}-0.4251 * * * \\
(-4.25)\end{array}$ & $\begin{array}{c}-0.3132 * * * \\
(-6.03)\end{array}$ \\
\hline $\begin{array}{l}\text { M2 (Quasi-money and money) } \\
(\% \text { of GDP in 1998) }\end{array}$ & $\begin{array}{c}0.3096^{* *} \\
(1.98)\end{array}$ & $\begin{array}{c}-0.0013 \\
(-0.67)\end{array}$ & $\begin{array}{c}-0.0047^{*} \\
(-1.73)\end{array}$ & $\begin{array}{c}-0.0063^{* * *} \\
(-2.41)\end{array}$ \\
\hline $\begin{array}{l}\text { Inflation } \\
(1998)\end{array}$ & $\begin{array}{c}-0.1508 \\
(-1.36)\end{array}$ & $\begin{array}{c}0.0088^{* * *} \\
(5.89)\end{array}$ & $\begin{array}{c}-0.0028 \\
(-1.57)\end{array}$ & $\begin{array}{c}-0.0063^{* * *} \\
(-3.96)\end{array}$ \\
\hline $\begin{array}{l}\text { GDP growth } \\
\text { (Average between } 1996 \text { and 1998) }\end{array}$ & $\begin{array}{l}0.4960 \\
(0.84) \\
\end{array}$ & $\begin{array}{c}-0.0530^{* * *} \\
(-5.42) \\
\end{array}$ & $\begin{array}{c}-0.0491 * * * \\
(-4.91)\end{array}$ & $\begin{array}{c}-0.0527 * * * \\
(-5.11) \\
\end{array}$ \\
\hline Log Likelihood & -5163.3 & -3046.4 & -2633.2 & -2747.6 \\
\hline
\end{tabular}

Data Source: The World Business Environment Survey (WBES) $\mathbb{0} 2000$ The World Bank Group.

Note: Regressions include dummy variables indicating ${ }^{a}$ region (Eastern Europe; Former Soviet Union; Caribbean; East $A$ sia; Latin America; Middle East and North Africa; South Asia; and Sub-Saharan Africa) and ${ }^{b}$ sector of operations (manufacturing, services, agriculture, and other). T-statistics are in parentheses. ${ }^{* * *} \mathrm{Sig}$. at $1 \%$ level ${ }^{* *} \mathrm{Sig}$. at $5 \%$ level $*$ Sig. at $10 \%$ level. 
Table VI: Effect of Foreign Bank Penetration on Enterprise's Access to Financing Including Interactions Between Foreign Bank Participation and Enterprise Size

\begin{tabular}{|c|c|c|c|c|}
\hline & (1) & (2) & (3) & (4) \\
\hline & Tobit & Ordered Probit & Ordered Probit & Ordered Probit \\
\hline $\begin{array}{l}\text { Obstacle } \\
\text { (High values indicate greater obstacle) }\end{array}$ & $\begin{array}{c}\% \text { of Investment } \\
\text { Financed through } \\
\text { Bank Loans }\end{array}$ & $\begin{array}{l}\text { High Interest } \\
\text { Rates }\end{array}$ & $\begin{array}{l}\text { Access to Long- } \\
\text { Term Loans }\end{array}$ & $\begin{array}{l}\text { Access to } \\
\text { Non-Bank } \\
\text { Financing }\end{array}$ \\
\hline Number of Observations & 2221 & 2948 & 2116 & 2231 \\
\hline Regional Dummies ${ }^{\text {a }}$ & Yes & Yes & Yes & Yes \\
\hline Sector of Operations ${ }^{b}$ & Yes & Yes & Yes & Yes \\
\hline \multicolumn{5}{|l|}{ Foreign Banks } \\
\hline $\begin{array}{l}\text { Foreign Banks Assets * Small Enterprise } \\
\text { (Interaction Term) }\end{array}$ & $\begin{array}{l}0.2330 \\
(1.43)\end{array}$ & $\begin{array}{c}-0.0048 * * * \\
(-2.35)\end{array}$ & $\begin{array}{c}-0.0144 * * * \\
(-4.91)\end{array}$ & $\begin{array}{l}-0.0020 \\
(-0.92)\end{array}$ \\
\hline $\begin{array}{l}\text { Foreign Banks Assets * Medium } \\
\text { Enterprise } \\
\text { (Interaction Term) }\end{array}$ & $\begin{array}{c}0.2625^{*} \\
(1.66)\end{array}$ & $\begin{array}{c}-0.0059 * * * \\
(-3.07)\end{array}$ & $\begin{array}{c}-0.0155 * * * \\
(-5,41)\end{array}$ & $\begin{array}{l}-0.0027 \\
(-1.34)\end{array}$ \\
\hline $\begin{array}{l}\text { Foreign Banks Assets * Large Enterprise } \\
\text { (Interaction Term) }\end{array}$ & $\begin{array}{c}0.3526^{*} \\
(1.73) \\
\end{array}$ & $\begin{array}{c}-0.0073 * * * \\
(-3.14) \\
\end{array}$ & $\begin{array}{c}-0.0167 * * * \\
(-4.62) \\
\end{array}$ & $\begin{array}{l}-0.0024 \\
(-0.94) \\
\end{array}$ \\
\hline \multicolumn{5}{|l|}{ Banking Sector } \\
\hline $\begin{array}{l}\text { Assets of } 5 \text { Largest Banks } \\
(\% \text { of total in 1999) }\end{array}$ & $\begin{array}{c}-0.2948^{*} \\
(-1.94)\end{array}$ & $\begin{array}{l}0.0021 \\
(0.91)\end{array}$ & $\begin{array}{c}0.0158 * * * \\
(5.44)\end{array}$ & $\begin{array}{l}0.0038 \\
(1.47)\end{array}$ \\
\hline $\begin{array}{l}\text { Assets of State-Owned Banks } \\
(\% \text { of total in 1999) }\end{array}$ & $\begin{array}{l}0.0795 \\
(0.58) \\
\end{array}$ & $\begin{array}{l}-0.0007 \\
(-0.43)\end{array}$ & $\begin{array}{c}0.0009 \\
(0.39)\end{array}$ & $\begin{array}{l}-0.0007 \\
(-0.38)\end{array}$ \\
\hline \multicolumn{5}{|l|}{ Enterprise Characteristics } \\
\hline $\begin{array}{l}\text { Small Enterprise } \\
\text { (Dummy Variable) }\end{array}$ & $\begin{array}{c}-19.384 * * * \\
(-2.93)\end{array}$ & $\begin{array}{c}-0.0021 \\
(-0.02)\end{array}$ & $\begin{array}{l}0.1196 \\
(0.93)\end{array}$ & $\begin{array}{c}0.1817^{*} \\
(1.73)\end{array}$ \\
\hline $\begin{array}{l}\text { Medium Enterprise } \\
\text { (Dummy Variable) }\end{array}$ & $\begin{array}{l}-5.9763 \\
(-1.00)\end{array}$ & $\begin{array}{l}0.1252 \\
(1.45) \\
\end{array}$ & $\begin{array}{r}-0.0037 \\
(-0.03)\end{array}$ & $\begin{array}{c}0.1746^{*} \\
(1.93)\end{array}$ \\
\hline $\begin{array}{l}\text { State Ownership } \\
(\% \text { of enterprise state owned) }\end{array}$ & $\begin{array}{c}-0.2837^{* * *} \\
(-4.47)\end{array}$ & $\begin{array}{c}-0.0035^{* * *} \\
(-3.81)\end{array}$ & $\begin{array}{c}-0.0040^{* * *} \\
(-3.83)\end{array}$ & $\begin{array}{c}-0.0014 \\
(-1.37)\end{array}$ \\
\hline $\begin{array}{l}\text { Foreign Ownership } \\
(\% \text { of enterprise foreign owned })\end{array}$ & $\begin{array}{l}0.0130 \\
(0.22) \\
\end{array}$ & $\begin{array}{c}-0.0025^{* * *} \\
(-2.93)\end{array}$ & $\begin{array}{c}-0.0044^{* * *} \\
(-3.90)\end{array}$ & $\begin{array}{c}-0.0049^{* * *} \\
(-5.17)\end{array}$ \\
\hline $\begin{array}{l}\text { Sales Growth } \\
(1996 \text { to } 1998)\end{array}$ & $\begin{array}{c}0.0361^{*} \\
(1.67)\end{array}$ & $\begin{array}{c}-0.0009 * * \\
(-2.41)\end{array}$ & $\begin{array}{l}0.0001 \\
(0.16)\end{array}$ & $\begin{array}{l}0.0004 \\
(0.95)\end{array}$ \\
\hline $\begin{array}{l}\text { Exports Growth } \\
(1996 \text { to } 1998)\end{array}$ & $\begin{array}{l}-0.0014 \\
(-0.04)\end{array}$ & $\begin{array}{r}-0.0002 \\
(-0.33)\end{array}$ & $\begin{array}{c}0.0006 \\
(0.79)\end{array}$ & $\begin{array}{l}0.0010 \\
(1.55)\end{array}$ \\
\hline $\begin{array}{l}\text { Enterprise Exports } \\
\text { (\% of sales) }\end{array}$ & $\begin{array}{c}0.0971^{*} \\
(1.87)\end{array}$ & $\begin{array}{l}-0.0009 \\
(-1.10)\end{array}$ & $\begin{array}{c}0.0021^{* *} \\
(2.01)\end{array}$ & $\begin{array}{l}0.0022^{* *} \\
(2.36)\end{array}$ \\
\hline $\begin{array}{l}\text { Operations outside of home country } \\
\text { (Dummy variable) }\end{array}$ & $\begin{array}{c}-5.4160 \\
(-1.21) \\
\end{array}$ & $\begin{array}{c}-0.0519 \\
(-0.75) \\
\end{array}$ & $\begin{array}{l}0.0051 \\
(0.06) \\
\end{array}$ & $\begin{array}{c}-0.0326 \\
(-0.45) \\
\end{array}$ \\
\hline \multicolumn{5}{|l|}{ Macroeconomic Factors } \\
\hline $\begin{array}{l}\text { Per Capita GDP } \\
\text { (Natural Log, 1998) }\end{array}$ & $\begin{array}{l}1.4602 \\
(0.27)\end{array}$ & $\begin{array}{c}-0.2685^{* * *} \\
(-5.09)\end{array}$ & $\begin{array}{c}-0.4255^{* * *} \\
(-4.25)\end{array}$ & $\begin{array}{c}-0.3134 * * * \\
(-6.03)\end{array}$ \\
\hline $\begin{array}{l}\text { M2 (Quasi-money and money) } \\
\text { (\% of GDP in 1998) }\end{array}$ & $\begin{array}{c}0.2988^{*} \\
(1.90)\end{array}$ & $\begin{array}{c}-0.0010 \\
(-0.52)\end{array}$ & $\begin{array}{c}-0.0044 \\
(-1.61)\end{array}$ & $\begin{array}{c}-0.0062 * * \\
(-2.39)\end{array}$ \\
\hline $\begin{array}{l}\text { Inflation } \\
(1998)\end{array}$ & $\begin{array}{c}-0.1530 \\
(-1.38)\end{array}$ & $\begin{array}{c}0.0089^{* * *} \\
(5.93)\end{array}$ & $\begin{array}{l}-0.0027 \\
(-1.52)\end{array}$ & $\begin{array}{c}-0.0063^{* * *} \\
(-3.93)\end{array}$ \\
\hline $\begin{array}{l}\text { GDP growth } \\
\text { (Average between } 1996 \text { and 1998) }\end{array}$ & $\begin{array}{l}0.5178 \\
(0.88)\end{array}$ & $\begin{array}{c}-0.0540 * * * \\
(-5.48)\end{array}$ & $\begin{array}{c}-0.0499 * * * \\
(-4.95)\end{array}$ & $\begin{array}{c}-0.0531 * * * \\
(-5.12)\end{array}$ \\
\hline Log Likelihood & 5163.1 & 3045.8 & 2633.0 & 2747.5 \\
\hline
\end{tabular}

Data Source: The World Business Environment Survey (WBES) 02000 The World Bank Group.

Note: Regressions include dummy variables indicating a region (Eastern Europe; Former Soviet Union; Caribbean; East Asia; Latin America; Middle East and North Africa; South Asia; and Sub-Saharan Africa) and ${ }^{\text {b }}$ sector of operations (manufacturing, services, agriculture, and other). T-statistics are in parentheses. ${ }^{* * *}$ Sig. at $1 \%$ level ${ }^{* *}$ Sig. at $5 \%$ level $*$ Sig. at $10 \%$ level. 
Table VII: Effect of Foreign Bank Penetration on Enterprise's Access to Financing Controlling for Bank Supervisory and Regulatory Variables

\begin{tabular}{|c|c|c|c|c|c|c|}
\hline & (1) & (2) & (3) & (4) & (5) & $(6)$ \\
\hline & Tobit & \multicolumn{2}{|c|}{ Ordered ProbitOrdered Probit } & Tobit & \multicolumn{2}{|c|}{ Ordered Probit Ordered Probit } \\
\hline $\begin{array}{l}\text { Obstacle } \\
\text { (High values indicate greater obstacle) }\end{array}$ & $\begin{array}{l}\% \text { of Investment } \\
\text { Financed } \\
\text { through Bank } \\
\text { Loans }\end{array}$ & $\begin{array}{l}\text { High Interest } \\
\text { Rates }\end{array}$ & \begin{tabular}{|c|} 
Access to Long- \\
Term Loans
\end{tabular} & $\begin{array}{l}\% \text { of Investment } \\
\text { Financed } \\
\text { through Bank } \\
\text { Loans }\end{array}$ & $\begin{array}{l}\text { High Interest } \\
\text { Rates }\end{array}$ & $\begin{array}{l}\text { Azcess to Long- } \\
\text { Term Loans }\end{array}$ \\
\hline Number of Observations & 3040 & 4065 & 3039 & 2099 & 2807 & 1985 \\
\hline Regional Dummies" & Yes & Yes & Yes & Yes & Yes & Yes \\
\hline Sector of Operations ${ }^{b}$ & Yes & Yes & Yes & Yes & Yes & Yes \\
\hline \multicolumn{7}{|l|}{ Foreign Banks } \\
\hline $\begin{array}{l}\text { Foreign Banks Assets * Small Ent. } \\
\text { (Interaction Term) }\end{array}$ & $\begin{array}{c}0.2095^{*} \\
(1.65)\end{array}$ & $\begin{array}{c}-0.0076^{* * *} \\
(-4.53)\end{array}$ & $\begin{array}{c}-0.0102^{* * *} \\
(-4.97)\end{array}$ & $\begin{array}{c}0.3666^{* *} \\
(2.13)\end{array}$ & $\begin{array}{c}-0.0071 * * * \\
(-2.98)\end{array}$ & $\begin{array}{c}-0.0150^{* * *} \\
(-4.96)\end{array}$ \\
\hline $\begin{array}{l}\text { Foreign Banks Assets * Medium Ent. } \\
\text { (Interaction Term) }\end{array}$ & $\begin{array}{c}0.3441^{* * *} \\
(2.82)\end{array}$ & $\begin{array}{c}-0.0061^{* * *} \\
(-3.69)\end{array}$ & $\begin{array}{c}-0.0097 * * * \\
(-4.61)\end{array}$ & $\begin{array}{c}0.3923^{* *} \\
(2.35)\end{array}$ & $\begin{array}{c}-0.0083^{* *} \\
(-3.62)\end{array}$ & $\begin{array}{c}-0.0178^{* * *} \\
(-5.98)\end{array}$ \\
\hline $\begin{array}{l}\text { Foreign Banks Assets * Large Ent. } \\
\text { (Interaction Term) }\end{array}$ & $\begin{array}{r}0.3215^{*} \\
(1.93) \\
\end{array}$ & $\begin{array}{c}-0.0084 * * * \\
(-4.13) \\
\end{array}$ & $\begin{array}{c}-0.0119^{* * *} \\
(-4.14)\end{array}$ & $\begin{array}{c}0.4306^{* *} \\
(2.03) \\
\end{array}$ & $\begin{array}{c}-0.0097^{* * *} \\
(-3.62)\end{array}$ & $\begin{array}{c}-0.0194 * * * \\
(-5.22) \\
\end{array}$ \\
\hline \multicolumn{7}{|l|}{ Banking Sector } \\
\hline $\begin{array}{l}\text { Assets of } 5 \text { Largest Banks } \\
(\% \text { of total in 1999) }\end{array}$ & $\begin{array}{r}-0.1395 \\
(-1.32)\end{array}$ & $\begin{array}{l}0.0014 \\
(0.82)\end{array}$ & $\begin{array}{c}0.0091^{* * *} \\
(4.53)\end{array}$ & $\begin{array}{r}-0.3402 \\
(-1.63)\end{array}$ & $\begin{array}{c}0.0057^{*} \\
(1.80)\end{array}$ & $\begin{array}{l}0.0197^{* * *} \\
(5.12)\end{array}$ \\
\hline $\begin{array}{l}\text { Assets of State-Owned Banks } \\
(\% \text { of total in 1999) }\end{array}$ & $\begin{array}{c}0.2294^{* *} \\
(2.20)\end{array}$ & $\begin{array}{l}-0.0002 \\
(-0.12) \\
\end{array}$ & $\begin{array}{l}0.0002 \\
(0.08) \\
\end{array}$ & $\begin{array}{l}0.1710 \\
(1.14) \\
\end{array}$ & $\begin{array}{c}-0.0010 \\
(-0.57) \\
\end{array}$ & $\begin{array}{r}0.0009 \\
(0.33) \\
\end{array}$ \\
\hline \multicolumn{7}{|l|}{ Bank Regulation } \\
\hline $\begin{array}{l}\text { Limits on Bank Entry } \\
\text { (Index - high values indicate more } \\
\text { restrictions) }\end{array}$ & & & & $\begin{array}{c}-5.2160^{* *} \\
(-2.41)\end{array}$ & $\begin{array}{l}0.0201 \\
(0.53)\end{array}$ & $\begin{array}{l}-0.0394 \\
(-0.95)\end{array}$ \\
\hline $\begin{array}{l}\text { Supervisory Power } \\
\text { (Index - high values indicate greater power) }\end{array}$ & & & & $\begin{array}{l}1.8786 \\
(1.50) \\
\end{array}$ & $\begin{array}{l}0.0078 \\
(0.51) \\
\end{array}$ & $\begin{array}{c}-0.0439^{* *} \\
(-2.06) \\
\end{array}$ \\
\hline \multicolumn{7}{|l|}{ Enterprise Level Variables } \\
\hline $\begin{array}{l}\text { Small Enterprise } \\
\text { (Dummy Variable) }\end{array}$ & $\begin{array}{c}-20.2162^{* * *} \\
(-3.69)\end{array}$ & $\begin{array}{l}0.0844 \\
(1.03)\end{array}$ & $\begin{array}{l}0.1351 \\
(1.30)\end{array}$ & $\begin{array}{c}-23.2786^{* * *} \\
(-3.39)\end{array}$ & $\begin{array}{l}0.0326 \\
(0.32)\end{array}$ & $\begin{array}{l}0.0339 \\
(0.25)\end{array}$ \\
\hline $\begin{array}{l}\text { Medium Enterprise } \\
\text { (Dummy Variable) }\end{array}$ & $\begin{array}{c}-10.5415^{* *} \\
(-2.07)\end{array}$ & $\begin{array}{l}0.1112 \\
(1.48)\end{array}$ & $\begin{array}{r}0.0031 \\
(0.03)\end{array}$ & $\begin{array}{l}-9.6431 \\
(-1.56)\end{array}$ & $\begin{array}{l}0.1358 \\
(1.51)\end{array}$ & $\begin{array}{l}-0.0054 \\
(-0.04)\end{array}$ \\
\hline $\begin{array}{l}\text { State Ownership } \\
(\% \text { of enterprise state owned })\end{array}$ & $\begin{array}{c}-0.2558^{* * *} \\
(-4.34)\end{array}$ & $\begin{array}{c}-0.0031 * * * \\
(-3.54)\end{array}$ & $\begin{array}{c}-0.0037^{* * *} \\
(-3.77)\end{array}$ & $\begin{array}{c}-0.3243^{* * *} \\
(-4.82)\end{array}$ & $\begin{array}{c}-0.0029^{* *} \\
(-2.95)\end{array}$ & $\begin{array}{c}-0.0030 * * * \\
(-2.66)\end{array}$ \\
\hline $\begin{array}{l}\text { Foreign Ownership } \\
\text { (\% of enterprise foreign owned) }\end{array}$ & $\begin{array}{l}-0.0160 \\
(-0.33)\end{array}$ & $\begin{array}{c}-0.0026^{* * *} \\
(-3.54)\end{array}$ & $\begin{array}{c}-0.0041^{* * *} \\
(-4.58)\end{array}$ & $\begin{array}{l}-0.0263 \\
(-0.44)\end{array}$ & $\begin{array}{c}-0.0022^{* *} \\
(-2.50)\end{array}$ & $\begin{array}{c}-10.0038 * * * \\
(-3.29)\end{array}$ \\
\hline $\begin{array}{l}\text { Sales Growth } \\
(1996 \text { to } 1998)\end{array}$ & & & & $\begin{array}{c}0.0377^{*} \\
(1.70)\end{array}$ & $\begin{array}{c}-0.0010^{* * *} \\
(-2.65)\end{array}$ & $\begin{array}{l}0.0002 \\
(0.58)\end{array}$ \\
\hline $\begin{array}{l}\text { Exports Growth } \\
\text { (1996 to 1998) }\end{array}$ & & & & $\begin{array}{r}-0.0025 \\
(-0.07)\end{array}$ & $\begin{array}{l}-0.0003 \\
(-0.52)\end{array}$ & $\begin{array}{l}0.0005 \\
(0.66)\end{array}$ \\
\hline $\begin{array}{l}\text { Enterprise Exports } \\
\text { (\% of sales) }\end{array}$ & $\begin{array}{c}0.1372^{* * *} \\
(3.06)\end{array}$ & $\begin{array}{c}-0.0012^{*} \\
(-1.67)\end{array}$ & $\begin{array}{c}0.0015^{*} \\
(1.65)\end{array}$ & $\begin{array}{l}0.1097^{* *} \\
(2.08)\end{array}$ & $\begin{array}{c}-0.0007 \\
(-0.79)\end{array}$ & $\begin{array}{c}0.0024^{* *} \\
(2.31)\end{array}$ \\
\hline $\begin{array}{l}\text { Operations outside of home country } \\
\text { (Dummy variable) }\end{array}$ & $\begin{array}{c}-2.2516 \\
(-0.61)\end{array}$ & $\begin{array}{c}-0.0929 \\
(-1.60)\end{array}$ & $\begin{array}{l}0.0094 \\
(0.14)\end{array}$ & $\begin{array}{r}-3.8301 \\
(-0.84) \\
\end{array}$ & $\begin{array}{c}-0.0310 \\
(-0.44)\end{array}$ & $\begin{array}{l}0.0056 \\
(0.06)\end{array}$ \\
\hline \multicolumn{7}{|l|}{ Macroeconomic Variables } \\
\hline $\begin{array}{l}\text { Per Capita GDP } \\
\text { Natural Log, 1998) }\end{array}$ & $\begin{array}{l}-2.5746 \\
(-0.65)\end{array}$ & $\begin{array}{c}-0.1451 * * \\
(-3.24)\end{array}$ & $\begin{array}{c}-0.1157^{*} \\
(-1.69)\end{array}$ & $\begin{array}{c}-0.2963 \\
(-0.05)\end{array}$ & $\begin{array}{c}-0.3364^{* * *} \\
(-5.68)\end{array}$ & $\begin{array}{c}-1) .5341^{* * *} \\
(-4.70)\end{array}$ \\
\hline $\begin{array}{l}\text { M2 (Quasi-money and money) } \\
(\% \text { of GDP in 1998) }\end{array}$ & $\begin{array}{c}0.5373^{* * *} \\
(4.90)\end{array}$ & $\begin{array}{l}-0.0012 \\
(-0.76)\end{array}$ & $\begin{array}{c}-0.0051 * * * \\
(-2.64)\end{array}$ & $\begin{array}{l}0.1057 \\
(0.54)\end{array}$ & $\begin{array}{l}0.0028 \\
(1.16)\end{array}$ & $\begin{array}{l}-0.0046 \\
(-1.52)\end{array}$ \\
\hline $\begin{array}{l}\text { Inflation } \\
(1998)\end{array}$ & $\begin{array}{c}-0.2153^{* *} \\
(-2.22)\end{array}$ & $\begin{array}{c}0.0079^{* * *} \\
(6.32)\end{array}$ & $\begin{array}{l}-0.0006 \\
(-0.41)\end{array}$ & $\begin{array}{c}-0.4665^{*} \\
(-1.81)\end{array}$ & $\begin{array}{c}0.0157^{* * *} \\
(5.70)\end{array}$ & $\begin{array}{l}-0.0024 \\
(-0.71)\end{array}$ \\
\hline $\begin{array}{l}\text { GDP growth } \\
\text { (Average between } 1996 \text { and } 1998 \text { ) }\end{array}$ & $\begin{array}{l}0.3883 \\
(0.72) \\
\end{array}$ & $\begin{array}{c}-0.0515^{* * *} \\
(-5.76) \\
\end{array}$ & $\begin{array}{c}-0.0520^{* * *} \\
(-5.70)\end{array}$ & $\begin{array}{l}-2.0603 \\
(-1.56)\end{array}$ & $\begin{array}{l}0.0011 \\
(0.05)\end{array}$ & $\begin{array}{c}-0.0434^{* *} \\
(-2.03)\end{array}$ \\
\hline Log Likelihood & -7556.5 & -4167.8 & -3827.0 & -4964.0 & -2885.5 & -2465.2 \\
\hline
\end{tabular}

Data Source: The World Business Environment Survey (WBES) 02000 The World Bank Group. Note: Regressions include dummy variables indicating a region (Eastern Europe; Former Soviet Union; Caribbean; East Asia; Latin America; Middle East and North Africa; South Asic; and Sub-Saharan Africa) and ${ }^{b}$ sector of operations (manufacturing, services, agriculture, and other). T-statistics are in parentheses. ${ }^{* * *}$ Sig. at $1 \%$ level ** Sig. at $5 \%$ level * Sig. at $10 \%$ level. 
Table VIII: Quantifying the Impact of Foreign Bank Penetration on Enterprises' Perceptions About Interest Rates and Access to Long-Term Loans

\begin{tabular}{|l|c|c|c|c|}
\hline Assets in Foreign Banks Set At & $\mathbf{2 0}^{\text {th }}$ Percentile & Median & $\mathbf{8 0}^{\text {th }}$ Percentile & $\begin{array}{c}\text { Change between } \\
\mathbf{2 0}^{\text {th }} \text { and } \mathbf{8 0}^{\text {th }} \\
\text { Percentiles }\end{array}$ \\
\hline Ave. Estimated Probability that Enterprise Will Rate High Interest Rates as a Major Problem \\
\hline All Enterprises & 0.647 & 0.618 & 0.551 & -0.096 \\
\hline Small & 0.632 & 0.608 & 0.551 & -0.081 \\
\hline Medium & 0.669 & 0.640 & 0.572 & -0.097 \\
\hline Large & 0.625 & 0.588 & 0.502 & -0.123 \\
\hline Ave. Estimated Probability that Enterprise Will Rate Access to Long-Term Loans as a Major Problem \\
\hline All Enterprises & 0.510 & 0.434 & 0.273 & -0.237 \\
\hline Small & 0.557 & 0.484 & 0.321 & -0.236 \\
\hline Medium & 0.470 & 0.394 & 0.237 & -0.233 \\
\hline Large & 0.498 & 0.417 & 0.247 & -0.251 \\
\hline
\end{tabular}

Note: Estimated probabilities are calculated for each enterprise using the coefficients from Table VI and setting all variables except for the share of assets in foreign banks at the actual level for that enterprise. Instead of using the actual value for the share of assets in foreign banks in the country that the enterprise operates, the calculation sets assets in foreign banks at the level of the $20^{\text {th }}$ percentile, the median level, and the level of the $80^{\text {th }}$ percentile for non-OECD countries. The probabilities are then averaged over all enterprises of that type.

Table IX: Quantifying the Effect of Macroeconomic Factors on Enterprises' Perceptions About Interest Rates and Access to Long-Term Loans

\begin{tabular}{|l|c|c|c|}
\hline & 20th Percentile & Median & 80th Percentile \\
\hline Ave. Estimated Probability that Enterprise Will Rate High & Interest Rates as a Major Problem \\
\hline Assets in 5 largest banks & 0.589 & 0.601 & 0.615 \\
\hline Assets in Government Banks & 0.617 & 0.611 & 0.597 \\
\hline Per Capita GDP & 0.707 & 0.630 & 0.566 \\
\hline M2 & 0.614 & 0.609 & 0.600 \\
\hline Inflation & 0.559 & 0.577 & 0.600 \\
\hline GDP growth & 0.605 & 0.569 & 0.540 \\
\hline Ave. Estimated Probability that Enterprise Will Rate Access to Long-Term Loans as a Major Problem \\
\hline Assets in 5 largest banks & 0.297 & 0.370 & 0.463 \\
\hline Assets in Government Banks & 0.377 & 0.382 & 0.393 \\
\hline Per Capita GDP & 0.587 & 0.455 & 0.355 \\
\hline M2 & 0.411 & 0.391 & 0.361 \\
\hline Inflation & 0.405 & 0.400 & 0.393 \\
\hline GDP growth & 0.384 & 0.351 & 0.326 \\
\hline
\end{tabular}

Note: Estimated probabilities are calculated for each enterprise using the coefficients from Table $\mathrm{V}$ and setting all variables except for the variable of interest at the actual level for that enterprise. Instead of using the actual value for the variable of interest in the country that the enterprise operates, the calculation sets assets held by foreign banks at the level of the $20^{\text {th }}$ percentile, the median level and the level of the $80^{\text {th }}$ percentile for non-OECD countries. The probabilities are then averaged over all enterprises. 
Table X: Cross-Country Results on Effect of Foreign Bank Penetration on Enterprise Financing

\begin{tabular}{|c|c|c|c|c|c|c|}
\hline & (1) & (2) & (3) & (4) & (5) & (6) \\
\hline & \multicolumn{3}{|c|}{ Medium and Large Enterprises } & \multicolumn{3}{|c|}{ Small Enterprises } \\
\hline & \multicolumn{6}{|c|}{ Ordinary Least Squares } \\
\hline $\begin{array}{l}\text { Obstacle } \\
\text { (High values indicate } \\
\text { greater obstacle) }\end{array}$ & \begin{tabular}{|c|}
$\%$ of \\
Investment \\
Financed \\
through \\
Bank \\
Loans \\
\end{tabular} & $\begin{array}{l}\text { High } \\
\text { Interest } \\
\text { Rates }\end{array}$ & $\begin{array}{c}\text { Access to } \\
\text { Long-Term } \\
\text { Loans }\end{array}$ & \begin{tabular}{|c|}
$\% \%$ of \\
Investment \\
Financed \\
through \\
Bank \\
Loans
\end{tabular} & $\begin{array}{l}\text { High } \\
\text { Interest } \\
\text { Rates }\end{array}$ & $\begin{array}{c}\text { Access to } \\
\text { Long-Term } \\
\text { Loans }\end{array}$ \\
\hline Number of Observations & 29 & 37 & 29 & 29 & 37 & 29 \\
\hline Regional Dummies ${ }^{\text {a }}$ & Yes & Yes & Yes & Yes & Yes & Yes \\
\hline \multicolumn{7}{|l|}{ Foreign Banks } \\
\hline $\begin{array}{l}\text { Assets of Foreign Banks } \\
(\% \text { of total in 1999) }\end{array}$ & $\begin{array}{c}0.2596^{* *} \\
(2.14)\end{array}$ & $\begin{array}{c}-0.0073^{* *} \\
(-2.09)\end{array}$ & $\begin{array}{c}-0.0125^{*} \\
(-1.84) \\
\end{array}$ & $\begin{array}{l}0.0256 \\
(0.24)\end{array}$ & $\begin{array}{c}-0.0041 \\
(-1.55)\end{array}$ & $\begin{array}{c}-0.0130^{*} \\
(-2.02)\end{array}$ \\
\hline \multicolumn{7}{|l|}{ Banking Sector } \\
\hline $\begin{array}{l}\text { Assets of } 5 \text { Largest Banks } \\
(\% \text { of total in 1999) }\end{array}$ & $\begin{array}{r}-0.1122 \\
(-0.88)\end{array}$ & $\begin{array}{l}0.0030 \\
(0.60)\end{array}$ & $\begin{array}{l}0.0133 \\
(1.70)\end{array}$ & $\begin{array}{l}-0.0623 \\
(-0.57)\end{array}$ & $\begin{array}{l}0.0000 \\
(0.01)\end{array}$ & $\begin{array}{l}0.0119 \\
(1.60)\end{array}$ \\
\hline $\begin{array}{l}\text { Assets of State-Owned Banks } \\
\text { \% of total in 1999) }\end{array}$ & $\begin{array}{c}0.2580^{* *} \\
(1.91) \\
\end{array}$ & $\begin{array}{r}0.0009 \\
(0.22) \\
\end{array}$ & $\begin{array}{r}0.0081 \\
(1.03) \\
\end{array}$ & $\begin{array}{l}0.0394 \\
(0.34)\end{array}$ & $\begin{array}{c}-0.0003 \\
(-0.09)\end{array}$ & $\begin{array}{c}-0.0060 \\
(-0.81)\end{array}$ \\
\hline \multicolumn{7}{|l|}{ Macroeconomic Variables } \\
\hline $\begin{array}{l}\text { Per Capita GDP } \\
(\text { Natural Log, 1998) }\end{array}$ & $\begin{array}{l}-5.2865 \\
(-1.08)\end{array}$ & $\begin{array}{l}-0.1417 \\
(-1.19)\end{array}$ & $\begin{array}{c}-0.3386 \\
(-1.21)\end{array}$ & $\begin{array}{c}-1.5987 \\
(-0.38)\end{array}$ & $\begin{array}{c}-0.1607^{*} \\
(-1.76)\end{array}$ & $\begin{array}{l}-0.0447 \\
(-0.17)\end{array}$ \\
\hline $\begin{array}{l}\text { M2 (Quasi-money and } \\
\text { money) } \\
(\% \text { of GDP in 1998) }\end{array}$ & $\begin{array}{c}0.2808^{* *} \\
(2.13)\end{array}$ & $\begin{array}{c}-0.0046 \\
(-0.96)\end{array}$ & $\begin{array}{c}-0.0048 \\
(-0.64)\end{array}$ & $\begin{array}{c}0.2406^{*} \\
(2.11)\end{array}$ & $\begin{array}{c}-0.0016 \\
(-0.44)\end{array}$ & $\begin{array}{c}-0.0094 \\
(-1.32)\end{array}$ \\
\hline $\begin{array}{l}\text { Inflation } \\
(1998)\end{array}$ & $\begin{array}{l}-0.0530 \\
(-0.46)\end{array}$ & $\begin{array}{c}0.0048 \\
(1.27)\end{array}$ & $\begin{array}{c}-0.0056 \\
(-0.84)\end{array}$ & $\begin{array}{c}-0.1134 \\
(-1.14)\end{array}$ & $\begin{array}{l}0.0041 \\
(1.38)\end{array}$ & $\begin{array}{c}-0.0004 \\
(-0.07)\end{array}$ \\
\hline $\begin{array}{l}\text { GDP growth } \\
\text { (Average between } 1996 \text { and } \\
1998 \text { ) }\end{array}$ & $\begin{array}{c}0.0554 \\
(0.08) \\
\end{array}$ & $\begin{array}{c}-0.0273 \\
(-0.99) \\
\end{array}$ & $\begin{array}{c}-0.0329 \\
(-0.81) \\
\end{array}$ & $\begin{array}{c}0.3038 \\
(0.52) \\
\end{array}$ & $\begin{array}{c}-0.0421^{* *} \\
(-1.98) \\
\end{array}$ & $\begin{array}{c}-0.0343 \\
(-0.89)\end{array}$ \\
\hline R-Squared & 0.71 & 0.61 & 0.65 & 0.69 & 0.66 & 0.64 \\
\hline
\end{tabular}

Note: Regressions include dummy variables indicating a region (Eastern Europe; Former Soviet Union; Caribbean; East A.sia; Latin America; Middle East and North Africa; South Asia; Sub-Saharan Africa and High-income OECD). T-statistics are in parentheses. ${ }^{* * *}$ Sig. at $1 \%$ level $* *$ Sig. at $5 \%$ level * Sig. at $10 \%$ level. 


\section{Endnotes}

${ }^{1}$ Demirgüç-Kunt et al. (1999) find a similar result. The measures of limitations on foreign entry and ownership and of more general entry requirements into banking used in Barth et al. (2001b) come from the survey of domestic regulators from 107 countries also used in this paper.

${ }^{2}$ Claessens et al. (2000) offer cross-country evidence that domestic banks are relatively inefficient in developing countries. Results from several country case studies support these findings. For example, Barajas et al. (2000) compare the performance of foreign and domestic banks in Colombia between 1985 and 1998, finding that foreignowned banks, regardless of whether they were originally owned by nationals or not, have fewer non-performing loans, lower reserve requirements, and are more productive. Clarke et al. (2000) find similar performance advantages for foreign banks operating in Argentina in the late 1990s. These results differ from those for developed ones where a number of studies have found that foreign-owned banks are, on average, less efficient than the domestic banks. See, for example, DeYoung and Nolle (1996), Hasan and Hunter (1996), Mahajan et al. (1996), Chang et al. (1998), Miller and Parkhe (1999), Parkhe and Miller (1999), and Berger et al. (2000b).

${ }^{3}$ Focarelli and Pozzolo (2000) model the location choices of 143 banks that had at least one shareholding abroad across 28 countries. Their dependent variable is a dummy equal to one if bank $i$ was present in country $j$ in 1998 . There are roughly 4000 bank-country observations in their regressions. They find greater entry where economic growth is expected to be higher and where the banking sector is less efficient. With respect to the efficiency of the host country banking market, they find greater foreign presence where local banks have higher average costs, lower net interest margins less charge-offs, higher cash flows (signaling an inefficient use of capital), and higher shares of non-interest income.

${ }^{4}$ There is also substantial evidence from the United States that indicates that large, although not necessarily foreign, banks lend smaller shares of their portfolios to small businesses than smaller banks. See, for example, Berger and Udell (1995), Berger et al. (1995), Keeton (1995), Levonian and Soller (1995), Berger and Udell (1996), Peek and Rosengren (1996), and Strahan and Weston (1996). This last paper finds a non-linear relationship between small business lending and bank size. Small business lending increases rapidly at first as banks become larger, leading to an increase in the ratio of small business loans to assets, but as banks become large enough to lend to large businesses, they start to do so, causing the share (but not the level) of lending to SMEs to drop.

${ }^{5}$ As reported in the American Banker, February 27, 1990, p. 18A.

${ }^{6}$ Due to data limitations, they measure size of borrowing firms based on their total debt within the system rather than on assets. They also run separate Logit models for the probability of receiving a loan from a large bank and the probability of receiving a loan from a foreign bank. This makes it harder to assess whether it is bank size or foreign ownership that limits access for small borrowers. Controlling for size, foreignness may not be that important a determinant of access.

${ }^{7}$ Given the available data, which did not include detailed information on cross-regional differences in lending, Clarke et al. (2001) could not test for competitive displacement effects in the four Latin American countries 
included in their study. However, there is evidence from the U.S. that consolidation may have a strong 'external effect' on lending by other banks. In particular, Berger et al. (1998) and Avery and Samolyk (2000) find that increased lending to small businesses by other incumbent banks in the same local markets offset much, if not all, of the negative quantity effects for the actual merger and acquisitions participants in the United States.

${ }^{8}$ This is true even in many middle-income countries. For example, in the late $1990 \mathrm{~s}$, there were only 28 commercial banks in Colombia, 19 commercial banks in Peru, 28 commercial banks in Chile, and 91 commercial banks in Argentina (Clarke et al., 2001).

${ }^{9}$ We are not aware of any sources that provide detailed data on total lending to SMEs that is comparable across countries. One reason why this is difficult is that regulators in different countries often have different reporting requirements and definitions for loans to SMEs. For example, in the four country case studies from Latin America in Clarke et al. (2001), two of the regulators collected data based upon loan size (Argentina and Peru), one required banks to keep separate records of loans to small businesses (Colombia), and one collected data based upon the tctal debt of the business (Chile).

${ }^{10}$ The survey was conducted in 70 developing and transition economies and in 9 OECD economies. The OECD countries are omitted from this analysis, which focuses on developing and transition economies. Hellman er al. (2000) provide a more complete description of the survey.

${ }^{11}$ Although some effort was made to ensure cross-country comparability, the degree of detail varied greatly between regions. For example, although data was collected on actual sales, fixed assets, and debts in some regions, only categorical data on the same information was collected in other regions.

${ }^{12}$ A score of 1 corresponded to the manager rating that issue as 'no obstacle', 2 as a 'minor obstacle', 3 as a 'moderate obstacle' and 4 as a 'major obstacle'.

${ }^{13}$ See, for example, Greene (2000, p. 376).

${ }^{14}$ Hellman et al. (2000) assess whether firms in any of 20 transition economies included in the WBES appeared to systematically over- or under-estimate the extent of several (non-financial sector) constraints by looking at the correlation of perceptions with measurable outcomes and then looking at unexplained residuals. They concluded that there was little evidence of any such bias in those countries (p. 8). They note, however, that their methodology did not constitute 'a precise statistical test' (p. 7).

${ }^{15}$ Barth et al. (2001) describe the data on bank regulation and supervision in far greater detail.

${ }^{16}$ The two indices are described in Table $I$ in Barth et al. (2001). The variables are "Entry into Banking Requirements" and "Official Supervisory Power". The measure of official supervisory power used in this paper omits one of 16 components, which asks whether the deposit insurance agency can take legal action against bank officials (Q8.6), since this variable is unavailable for many of the countries included in this analysis.

${ }^{17}$ In particular, managers were asked to respond to questions such as "using [a four-point scale], can you please tell in turn how problematic are these different financing issues [high interest rates, access to long-term loans, and access to non-bank financing ] for the operation and growth of your business." The scores are as follows: 1 indicates no obstacle, 2 indicates a minor obstacle, 3 indicates a moderate obstacle, and 4 indicates a major obstacle. 
${ }^{18}$ Since the index increases as enterprises' perceptions about the obstacle imposed by the various constraints increase, the negative coefficient on foreign penetration implies that greater foreign penetration is correlated with improved perceptions.

${ }^{19}$ We use these size definitions because these are the definitions provided in the survey based on number of employees. Although greater information on number of employees was available for countries in Eastern Europe, similar data were not available in other regions. Number of employees seems a reasonable way to compare enterprises across countries because it avoids problems related to accounting differences, exchange rates, and relative income in different countries. See footnote 20 for a discussion of results using a different definition of enterprise size.

${ }^{20}$ In addition to the analysis including dummies and interaction terms based on number of employees, we also estimated similar regressions including size dummies and interaction terms based upon dividing the sample of enterprises into ten groups based on the dollar value of the enterprises' fixed assets. This was the finest division that we could do - the WBES data for some countries only included categorical data (10 categories) on the value of fixed assets. The results were broadly similar to the results here. In particular, the coefficient on bank assets held by foreign banks remained statistically significant and kept the same sign in the three regressions where it was statistically significant in previous regressions. In the final regression, on access to non-bank equity, the coefficient remained statistically insignificant. In most cases (34 out of 36 coefficients), we were unable to reject the null hypothesis that the coefficient on the interaction term was the same for enterprises of different sizes.

${ }^{21}$ Average estimated probabilities are calculated using the coefficients from columns 1 and 2 of Table VI. All variables except the variable of interest (in this case assets of foreign banks) are set at their actual level for that enterprise. The variable of interest is set at the same level (e.g., the median level for developing countries in the sample) for all enterprises. Using these values, the estimated probability that the enterprise would rate that constraint as a 'major' constraint for that level of the variable of interest is calculated. The average estimated probability is then calculated by averaging over all enterprises of that type.

${ }^{22}$ The $\chi^{2}(2)$ statistic for the likelihood ratio test that the coefficients on the interaction terms are equal in the regressions for share of investment, high interest rates, and access to long-term loans are 0.4, 1.2, and 0.4, respectively.

${ }^{23}$ One difference might be that public banks are more likely to finance government expenditures. For example, in 1990, before the Convertibility plan restricted lending from the provincial banks to finance provincial deficits, public provincial banks in Argentina financed over 60 percent of provincial government's deficits (Clarke and Cull, forthcoming). Even after the Convertibility Plan, provincially owned public banks tended to lend more to the government and public enterprises than private banks (Clarke and Cull, 1999, p. 876).

${ }^{24}$ See footnote 21 for a description of how estimated average probabilities are calculated. 
${ }^{25}$ These results differ somewhat from cross-country evidence in that greater concentration is not closely associated with banking sector efficiency, financial development, or industrial competition (Demirgüç-Kunt and Levine, 2000), and has little effect on bank profitability and margins (Demirgüç-Kunt and Huizinga, 1999).

${ }^{26}$ It is important to note that most foreign-owned enterprises in our sample are large, so the finding that even small firms benefit from foreign penetration is not driven by their foreign ownership status.

${ }^{27}$ See, for example, Aw and Hwang (1995); Bernard and Jensen (1999); Chen and Tang (1998) and Clerides et al. (1998).

${ }^{28}$ In addition to these control variables, regional dummies are included. The regions are: Eastern Europe; the Commonwealth of Independent States; the Caribbean; East Asia; Latin America; the Middle East and North Africa; South Asia; and Sub-Saharan Africa.

${ }^{29}$ In some model specifications rather than including the ratio of money to quasi-money to GDP, we replaced this variable with the ratio of credit to the private sector to GDP. This did not have a large impact on the main results. In particular, the coefficients on assets held by foreign banks and assets held by the five largest banks remained significant at similar significance levels (or higher) to those in Table V.

${ }^{30}$ The market concentration and the restrictions on entry variables are correlated (.28), but not too highly. The concentration measure is affected not only by entry restrictions, but also by general economic and banking conditions and other aspects of bank regulation and supervision such as the stringency of capital and reserve requirements. It is not too surprising, therefore, that both variables enter significantly in some regressions.

${ }^{31}$ In addition, regional dummies are included in all regressions. Results for access to non-bank financing are omitted from the tables since foreign bank penetration did not appear to affect access to non-bank financing in the previous regressions. In similar cross-country regressions for this variable to the ones presented in Table X, the coefficient on assets on foreign banks is statistically insignificant for both large and small enterprises. 




\section{Policy Research Working Paper Series}

\section{Title}

WPS2693 Helping People Help Themselves:

Toward a Theory of Autonomy-

Compatible Help

WPS2694 Financial Development and Financing Constraints: International Evidence from the Structural Investment Model

WPS2695 Trade, Credit, Financial Intermediary Development, and Industry Growth

WPS2696 Firms as Financial Intermediaries: Evidence from Trade Credit Data

WPS2697 Regional Integration and Industrial Growth among Developing Countries: The Case of Three ASEAN Members

WPS2698 Foreign Bank Entry: Experience, Implications for Developing Countries, and Agenda for Further Research

WPS2699 Benefits and Costs of International Financial Integration: Theory and Facts

WPS2700 Business Cycles, Economic Crises, and the Poor: Testing for Asymmetric Effects

WPS2701 Trade and Production, 1976-99

WPS2702 Productivity versus Endowments: A Study of Singapore's Sectoral Growth, 1974-92

WPS2703 Integrating Independent Power Producers into Em rrging Wholesale Power Markets

WPS2704 Regulatory Governance and Chile's 1998-99 Electricity Shortage

WPS2705 Concession Contraci Renegotiations: Some Efficiency versus Fquity Dilemmas
George Clarke

Asli Demirgüç-Kunt

Vojislav Maksimovic

Dorsati H. Madani

Robert Cull

Maria Soledad Martinez Peria

Susana M. Sánchez

Pierre-Richard Agénor

Pierre-Richard Agénor

Alessandro Nicita

Marcelo Olarreaga

Hiau Looi Kee

Fiona Woolf

Jonathan Halpern

Ronald Fischer

Alexander Galetovic

Antonio Estache

Lucía Quesada

\section{Date}

October 2001

October 2001

October 2001

October 2001

October 2001

October 2001

October 2001

November 2001

November 2001

Contact for paper

B. Mekuria 82756

K. Labrie 31001

K. Labrie 31001

K. Labrie 31001

L. Tabada 36896

P. Sintim-Aboagye 38526

M. Gosiengfiao 33363

M. Gosiengfiao 33363

L. Tabada 36896

L. Tabada 36896

November 2001

Energy Help Desk 30652

Nuvember 2001

G. Chenet-Smith 36370

November 2001
G. Chenet-Smith 3637 ? 


\section{Policy Research Working Paper Series}

Title

\author{
WPS2706 Household Income Dynamics \\ in Rural China \\ WPS2707 Financial Intermediary Development \\ and Growth Volatility: Do \\ Intermediaries Dampen or Magnify \\ Shocks? \\ WPS2708 Accountability and Corruption: \\ Political Institutions Matter
}

WPS2709 Explaining Leakage of Public Funds

WPS2710 Breaking up the Collective Farm: Welfare Outcomes of Vietnam's Massive Land Privatization

WPS2711 Identifying Class Size Effects in Developing Countries: Evidence from Rural Schools in Bolivia

WPS2712 Contract Risks and Credit Spread Determinants in the International Project Bond Market

WPS2713 Causes of Inequality in Health: Who You Are? Where You Live? Or Who Your Parents Were?

WPS2714 On Decomposing the Causes of Health Sector Inequalities with an Application to Malnutrition Inequalities Naoko Watanabe in Vietnam

WPS2715 Paying fo tealth Care: Quantifying Fairness, Catastrophe, and Impoverishment, with Applications to Vietnam, 1993-98 Adam Wagstaff

Author

Jyotsna Jalan Martin Ravallion

Thorsten Beck

Mattias Lundberg

Giovanni Majnon:

Daniel Lederman

Norman Loayza

Rodrigo Reis Soares

Ritva Reinikka

Jakob Svensson

Martin Ravallion

Dominique van de Walle

Miguel Urquiola

Mansoor Dailami

Robert Hauswald

Adam Wagstaff

Pierella Paci

Heather Joshi

Adam Wagstaff

Eddy van Doorsiaer

Eddy van Doorslaer

\section{Date}

November 2001

November 2001

November 2001

November 2001

November 2001

November 2001

November 2001

November 2001

November 2001

ovember 2001

\section{Contact} for paper

C. Cunanan 32301

A. Yaptenco 38526

P. Soto

37892

H. Sladovich 37698

C. Cunanan 32301

H. Sladovich 37698

W. Nedrow 31585

H. Sladovich 37698

H. Sladovich 37698

H. Sladovich 37698 